\title{
The Lung in Dysregulated States of Humoral Immunity
}

\author{
Yurdagül Uzunhan ${ }^{\mathrm{a}, \mathrm{b}} \quad$ Florence Jeny $^{\mathrm{a}, \mathrm{b}}$ Marianne Kambouchner ${ }^{\mathrm{c}}$ \\ Morgane Didier $^{a, b}$ Diane Bouvry ${ }^{a, b}$ Hilario Nunes $^{a, b}$ \\ Jean-François Bernaudin ${ }^{b, d}$ Dominique Valeyre ${ }^{a, b}$

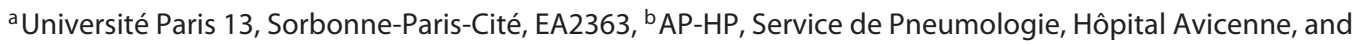 \\ 'AP-HP, Service d'Anatomie Pathologique, Hôpital Avicenne, Bobigny, dUPMC Paris 6, Paris Sorbonne Universités, \\ Paris, France
}

\section{Keywords}

Common variable immunodeficiency · lgG4 • Amyloidosis . Lung · Humoral immunity · Light-chain deposition disease

\begin{abstract}
In common variable immunodeficiency, lung manifestations are related to different mechanisms: recurrent pneumonias due to encapsulated bacteria responsible for diffuse bronchiectasis, diffuse infiltrative pneumonia with various patterns, and lymphomas, mostly B cell extranodal non-Hodgkin type. The diagnosis relies on significant serum Ig deficiency and the exclusion of any primary or secondary cause. Histopathology may be needed. Immunoglobulin (IgG) replacement is crucial to prevent infections and bronchiectasis. IgG4-related respiratory disease, often associated with extrapulmonary localizations, presents with solitary nodules or masses, diffuse interstitial lung diseases, bronchiolitis, lymphadenopathy, and pleural or pericardial involvement. Diagnosis relies on international criteria including serum IgG4 dosage and significantly increased lgG4/lgG plasma cells ratio in pathologically suggestive biopsy. Respiratory amyloidosis presents with tracheobronchial, nodular, and
\end{abstract}

\section{KARGER}

(C) 2017 S. Karger AG, Basel

E-Mail karger@karger.com

www.karger.com/res cystic or diffuse interstitial lung infiltration. Usually of $A L$ (amyloid light chain) subtype, it may be localized or systemic, primary or secondary to a lymphoproliferative process. Very rare other diseases due to nonamyloid IgG deposits are described. Among the various lung manifestations of dysregulated states of humoral immunity, this article covers only those associated with the common variable immunodeficiency, IgG4-related disease, amyloidosis, and pulmonary light-chain deposition disease. Autoimmune connective-vascular tissue diseases or lymphoproliferative disorders are addressed in other chapters of this issue.

(c) 2017 S. Karger AG, Basel

Yurdagül Uzunhan and Florence Jeny contributed equally to this article.

Previous articles in this series: 1. Lazor R, Nicod LP: The lung in rare systemic diseases. Respiration 2017;94:1. 2. Tran C, Barbey F, Lazor R, Bonafé L: Pulmonary involvement in adult patients with inborn errors of metabolism. Respiration 2017;94:2-13. 3. Borie R, Wislez M, Antoine M, Cadranel J: Lymphoproliferative disorders of the lung. Respiration 2017;94:157-175. 4. Dupuis-Girod S, Cottin V, Shovlin $\mathrm{CL}$ : The lung in hereditary hemorrhagic telangiectasia. Respiration 2017;94:315-330.
Yurdagül Uzunhan, MD, PhD

Service de Pneumologie, Hôpital Avicenne

125 rue de Stalingrad

FR-93009 Bobigny (France)

E-Mail yurdagul.uzunhan@aphp.fr 
Table 1. Criteria for a probable diagnosis of common variable immunodeficiency adapted from the European Society of Immunodeficiency Registry [5]

\begin{tabular}{|c|c|}
\hline Clinical criteria for a probable diagnosis (= clinical diagnosis) & $\begin{array}{l}\text { Suggestions for alternative diagnosis (i.e., } \\
\text { if these criteria are not completely } \\
\text { fulfilled) }\end{array}$ \\
\hline $\begin{array}{l}\text { At least one of the following } \\
\text { - Increased susceptibility to infection } \\
\text { - Autoimmune manifestations } \\
\text { - Granulomatous disease } \\
\text { - Unexplained polyclonal lymphoproliferation } \\
\text { - Affected family member with antibody deficiency } \\
\text { AND marked decrease of IgG and marked decrease of IgA with or without low IgM } \\
\text { levels (measured at least twice; }<2 \text { SD of age-related normal value); } \\
\text { AND at least one of the following: } \\
\text { - Poor antibody response to vaccines } \\
\text { - Few switched memory B cells (<70\% of age-related normal value) } \\
\text { AND exclusion of secondary causes of hypogammaglobulinemia }{ }^{\mathrm{a}} \\
\text { AND diagnosis established after the } 4 \text { th year of life (but symptoms may precede) } \\
\text { AND no evidence of profound T-cell deficiency }\end{array}$ & $\begin{array}{l}\text { For patients }<4 \text { years old or patients with } \\
\text { incomplete criteria consider "unclassified } \\
\text { antibody deficiency" } \\
\text { For patients with evidence of profound } \\
\text { T-cell deficiency, consider unclassified } \\
\text { combined immunodeficiencies }\end{array}$ \\
\hline
\end{tabular}

a Other causes of hypogammaglobulinemia, such as primary immunodeficiency syndromes (e.g., X-linked agammaglobulinemia, hyper-IgM Good's syndrome) and secondary causes of hypogammaglobulinemia (protein loss enteropathy, nephrotic syndrome, Good's syndrome, drug, lymphoid, etc. ) [3, 4, 8] must be excluded. ${ }^{b}$ According to Bertinchamp et al. [6].

\section{Lung Manifestations in Common Variable Immunodeficiency}

Common variable immunodeficiency (CVID), a group of disorders [1], is characterized by a loss of B-cell function with low levels of IgG $<5 \mathrm{~g} / \mathrm{L}[2,3]$ and IgA, with various IgM levels, associated with defective antibody responses [4]. The primary and secondary causes of hypogammaglobulinemia should be excluded as in profound T-cell deficiency. Recently, national and international medical societies have specified diagnostic criteria [3, 5-7] (those from European Society for Immunodeficiencies [ESID] are shown in Table 1) [5]. With an overall prevalence between $1 / 25,000$ and $1 / 50,000$ [8, 9], CVID is less common among Asians and rare among Blacks [2, 10]. CVID is mostly diagnosed in 20- to 40-year-old adults with a male/female ratio of $1[2,4,11]$, while a first peak, particularly in males, is observed before the age of 10 [11]. A delay of 4-5 years in diagnosis is common [11]. No cause has been established except an autosomal dominant inheritance in some patients [12-14]. The common immune defect in CVID is a loss in B cell function either intrinsic or resulting from $\mathrm{T}$ cell defects in their collaboration for antibody production, which results in a reduction in isotype-switched B and plasma cells in bone mar- row and mucosal tissues [15]. Recurrent naso-sinusal and pulmonary infections by encapsulated bacteria (Haemophilus influenza and Streptococcus pneumoniae) are the most frequent presentations $[2,16]$. CVID may be associated with autoimmune features (particularly cytopenia) in $20-68 \%$ of cases, lymphocytic infiltration, and malignancy (lymphoid or solid tumors) [1, 11, 16-18]. These noninfectious complications increase significantly the mortality and morbidity, and impact quality of life [1, $16,19]$.

Bronchiectasis in CVID is a common complication of recurrent pneumonia [20] with an estimated prevalence of $23 \%$ [11]. The risk of developing bronchiectasis increases with diagnostic delay [11], age [21], complete IgA or IgM deficits, a decreased number of blood memory B cells, a low number of CD4+ T cells, and low circulating mannose binding lectins levels [11, 21-23]. At baseline, chest computed tomography (CT) and pulmonary function tests (PFTs) are recommended [7]. Bronchiectases are cylindrical, bilateral and diffuse, and preferentially located in middle and lower lobes $[24,25]$. Bronchial thickening might be due to bronchial inflammation preceding the development of bronchiectasis [25]. Bronchiectasis may lead to Staphylococcus aureus, or Pseudomonas aeruginosa infection, hemoptysis and respiratory failure. If as- 
sociated with functional or parenchymal abnormalities, bronchiectasis predicts poor outcome [16]. In addition to immunoglobulin (IgG) replacement, the treatment of bronchiectasis in CVID is the same as for any other cause [7]. Sputum clearance respiratory physiotherapy, inhaled corticosteroid \pm long-acting beta-agonists [26] and longterm antibiotic prophylaxis with azithromycin [27] may be useful. Inactivated influenza vaccine is recommended $[7,28]$. IgG replacement must use high doses $(0.6 \mathrm{~g} / \mathrm{kg} /$ month) $[7,29]$ as high rates of respiratory infections and poor outcome are associated with suboptimal IgG replacement $[11,29,30]$. Some patients may nevertheless develop bronchiectasis despite IgG replacement therapy [31]. In practice, early diagnosis and prompt initiation of IgG replacement can prevent lower respiratory tract infections and bronchiectasis [32, 33].

Various interstitial lung diseases (ILD) have been observed in CVID (CVID-ILD): lymphoid interstitial pneumonia, organizing pneumonia, granulomatous lung disease, hypersensitivity pneumonitis, or malignancy such as lymphoma [34, 35]. Granulomatous lymphocytic ILD (GLILD) encompasses granulomatous and lymphoid infiltration $[34,36]$. Lung granulomatosis may be part of a systemic granulomatosis with extrathoracic involvement simulating sarcoidosis [37-39]. However, extrathoracic granulomas do not predict the granulomatous nature of the associated ILD [40]. Patients with GLILD usually present with dyspnea, cough, and crackles $[34,37]$. The prevalence of GLILD among CVID patients is approximately $10-15 \%[32,41]$. The average delay between CVID diagnosis and GLILD detection is 7.8 years $[32,38,42]$. A restrictive profile at PFTs is observed with reduced carbon monoxide diffusion capacity (DLCO) [43]. Bronchoalveolar lavage (BAL) is useful for investigating infections, while GLILD has been associated with BAL lymphocytosis (>20\%) with a variable CD4/CD8 ratio [37, 44]. Granulomatous disease frequently affects the liver, spleen, and skin [37-39]. Immune thrombocytopenia or hemolytic anemia, splenomegaly, polyarthritis, a decrease in switched memory B cells, high blood CD4/CD8 $\mathrm{T}$ cell ratio, and high serum IgM may help identify patients with GLILD [21, 32, 34, 45]. PFTs and thoracic CT at baseline plus every year for PFTs and every 5 years for CT are recommended in CVID-ILD [7, 46]. ${ }^{18 \mathrm{~F}} \mathrm{FDG}-$ $\mathrm{PET} / \mathrm{CT}$ shows an increased uptake in lungs or extrathoracic organs [47]. Lung MRI with diffusion may be useful for detecting bronchial and parenchymal abnormalities for long-term follow-up [48]. On CT, GLILD shows diffuse reticulations, ground-glass opacities and consolidation, with lower lobe predominance $[32,34]$ (Fig. 1). Me-

The Lung in Dysregulated States of Humoral Immunity

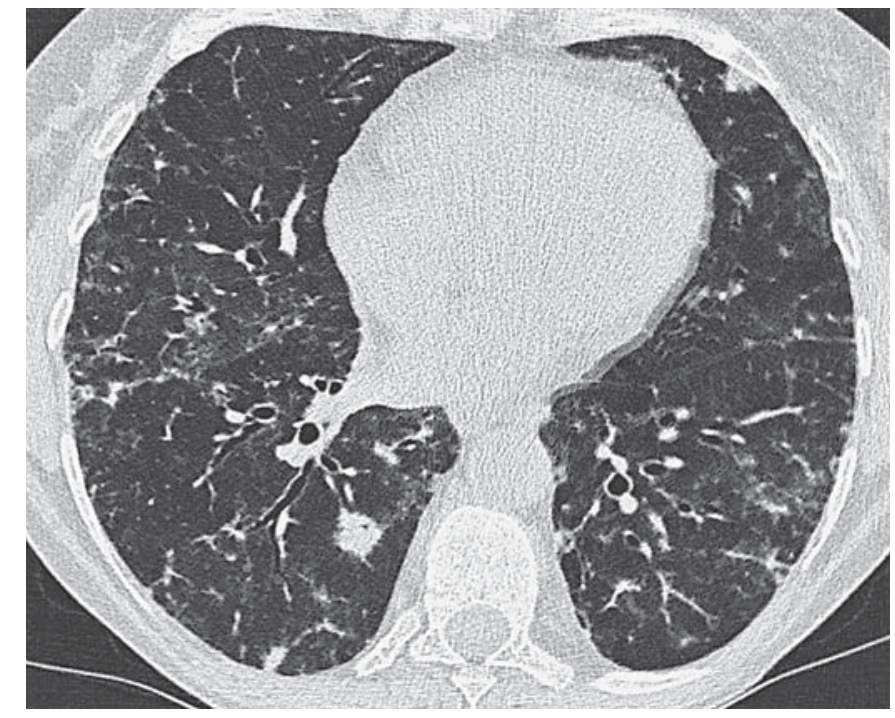

Fig. 1. Thoracic computed tomography of a patient with a CVID showing nodules, ground glass opacification micronodules, bronchiectasis, and reticulation with a lower lobe predominance.

diastinal lymphadenopathy, micronodules, interlobular septal thickening, and cysts are also seen in CVID-ILD $[32,49,50]$. Contrary to sarcoidosis, nodules, air bronchogram, halo sign, and bronchiectasis are frequent in CVID-associated granulomatous disease with no perilymphatic predominant distribution of micronodules [37]. The prognosis of GLILD is poor, with median survival of 13.7 years versus 28.8 years in CVID without GLILD [1,34]. Suboptimal IgG replacement, elevated $\operatorname{IgM}$, and severe thrombocytopenic episodes lead to a higher risk of progressive disease [51]. Immunomodulatory treatments may be beneficial to some patients [51]. Immunosuppressive agents expose to infectious and malignant diseases. Monitoring corticosteroid-induced CD4 lymphopenia and pneumocystis prophylaxis are recommended [46]. Despite weak evidence of efficacy, corticosteroids may be used as first-line therapy [38]. Immunosuppressive steroid-sparing agents showed variable success. The azathioprine and rituximab combination was found effective in a small series of GLILD patients, with improved spirometry and imaging [41]. For prominent $\mathrm{T}$ cell infiltration, corticosteroids with or without cyclosporine have been successful [52]. Infliximab has also been successful for granulomatous disease in case reports [53]. Lung transplantation should be considered in the case of refractory progressive disease [54]. The incidence of malignancy is increased in CVID, particularly lymphoma,

Respiration 2017;94:389-404 DOI: $10.1159 / 000480297$ 
which occurs in up to $3-8 \%$ of patients $[11,16]$. Lymphomas are more common in patients aged between 30 and 60 years and in females $[13,16]$. They usually are B cell extranodal non-Hodgkin lymphomas $[16,55]$. Genetic aberrations, chronic infection, and immune dysregulation $[56,57]$ are suggested to explain the increased lymphoma incidence. Lung mucosa-associated lymphoid tissue (MALT) has been reported, occasionally related to Helicobacter pylori $[58,59]$. At CT, MALT lymphomas manifest as chronic localized opacities including consolidations, nodules, and masses with the presence of airways within the lesions in $85 \%[60,61]$. After respiratory failure, lymphoma is the second cause of death in CVID [16].

\section{IgG4-Related Respiratory Disease}

Since the initial report of a patient with sclerosing cholangitis associated with an elevated serum IgG4 concentration [62], IgG4-related disease (IgG4-RD) has been defined as a multiorgan chronic fibroinflammatory condition characterized by lymphoplasmacytic infiltrates with abundant IgG4 plasma cells, associated with storiform fibrosis and often high serum IgG4 concentrations $[63,64]$. Fibroinflammatory lesions may virtually affect every organ [63]. Presentation is highly diverse, including autoimmune pancreatitis, sialadenitis, dacryoadenitis, lymphadenopathy, periaortitis/retroperitoneal fibrosis and tubulointerstitial nephritis [64, 65]. Uchida et al. [66] estimated the annual incidence and prevalence of IgG4$\mathrm{RD}$ in Japan to be $0.28-1.08 / 100,000$ and $6 / 100,000$, respectively. IgG4-RD affects middle- to old-age (median age: 50.3-67) subjects, with a male/female ratio ranging from 1.6:1 to 4:1 [63, 67, 68]. IgG4-RD immunopathogenesis remains incompletely elucidated. It includes oligoclonal expansion of plasmablasts as well as CD4+ T cytotoxic cells [69-71]. Oligoclonal expansion of circulating CD19+CD20-CD27+CD38+ plasmablasts reflects the disease activity [72]. The implication of IgG4 is uncertain as they have noninflammatory properties in contrast with other IgG subclasses [69, 73]. IgG4 increase might represent an ineffective attempt to downregulate the ongoing primary inflammatory response triggered by still unknown antigens. However, IgG4 might be pathogenic through interaction with circulating lectins to activate complement [74]. Neither causal antigens nor at risk occupational exposure has been identified so far [75].

Since the first report of ILD associated with autoimmune pancreatitis [76], various presentations of intrathoracic IgG4-RD have been described: ILD, lung nodules, bronchial inflammation, mediastinitis, and pleuritis [64, $65,77,78]$. IgG4-related respiratory disease (IgG4-RRD) has been proposed to refer to pulmonary and other intrathoracic organ involvement [79]. Thoracic manifestations are estimated to represent $13-35 \%$ of all IgG4-RD $[67,68,80-83]$.

These may occur in isolation [84] in $20 \%$ of patients [68] but most often accompany 2 or more extrapulmonary localizations $[75,81,85]$. Extrapulmonary manifestations may be synchronous or metachronous with those affecting the lung [86]. IgG4-RD presentation typically includes 5-10 kg weight loss and fatigue for months or even years before diagnosis [64]. While fever is unusual in IgG4-RD, it might be more frequent in patients with intrathoracic involvement [85]. Many patients with or without intrathoracic involvement have ear, nose, and throat symptoms [64], especially in the absence of atopy [87]. Thoracic symptoms include cough, hemoptysis, dyspnea, and chest pain $[84,86]$. However, half of the patients are asymptomatic $[85,86]$. Four main CT pulmonary patterns of IgG4-RRD have been reported [86]: (i) solitary solid nodule or mass, (ii) bronchovascular bundles and interlobular septa thickening, (iii) alveolointerstitial pattern showing honeycombing, bronchiectasis, and diffuse ground glass opacities (GGO) with possible multiple small nodules, (iv) less frequently multiple round-shaped GGO [85]. Consolidations and bronchiolitis have also been reported [84, 88, 89]. Enlarged lymphadenopathy is present in half of the cases $[85,86]$. Often asymmetrical or solitary [85], it may be similar to sarcoidosis [90, 91]. Fibrosing mediastinitis [92, 93], nodular lesions, or pleura thickening may be seen $[85,86]$. Although rare, pericardial effusion or thickening [85] may lead to constrictive pericarditis or cardiac tamponade [94]. All these lesions may be associated (Fig. 2).

${ }^{18 \mathrm{~F}} \mathrm{FDG}$-PET/CT is considered very helpful to guide biopsy and monitor treatment [95]. The characteristic pattern of ${ }^{18 \mathrm{~F}} \mathrm{FDG}$ uptake in IgG4-RD is a symmetrical distribution in the salivary glands, diffuse in the enlarged pancreas without duct obstruction, patchy in the aorta wall or in retroperitoneal lesions [95].

PFTs are often normal, but obstructive or restrictive profiles [75] or decreased diffusion capacity may be observed [78]. Pulmonary hypertension (PH) caused by obliterative phlebitis due to IgG4-positive plasma cell infiltration has been reported [96].

Measurement of serum IgG4 concentration evaluation is important in the workup and outcome assessment of IgG4-RD patients, but a level $>135 \mathrm{mg} / \mathrm{dL}$ is neither necessary nor sufficient for diagnosis [97]. Around 50\% of
392

Respiration 2017;94:389-404

DOI: $10.1159 / 000480297$
Uzunhan/Jeny/Kambouchner/Didier/

Bouvry/Nunes/Bernaudin/Valeyre 


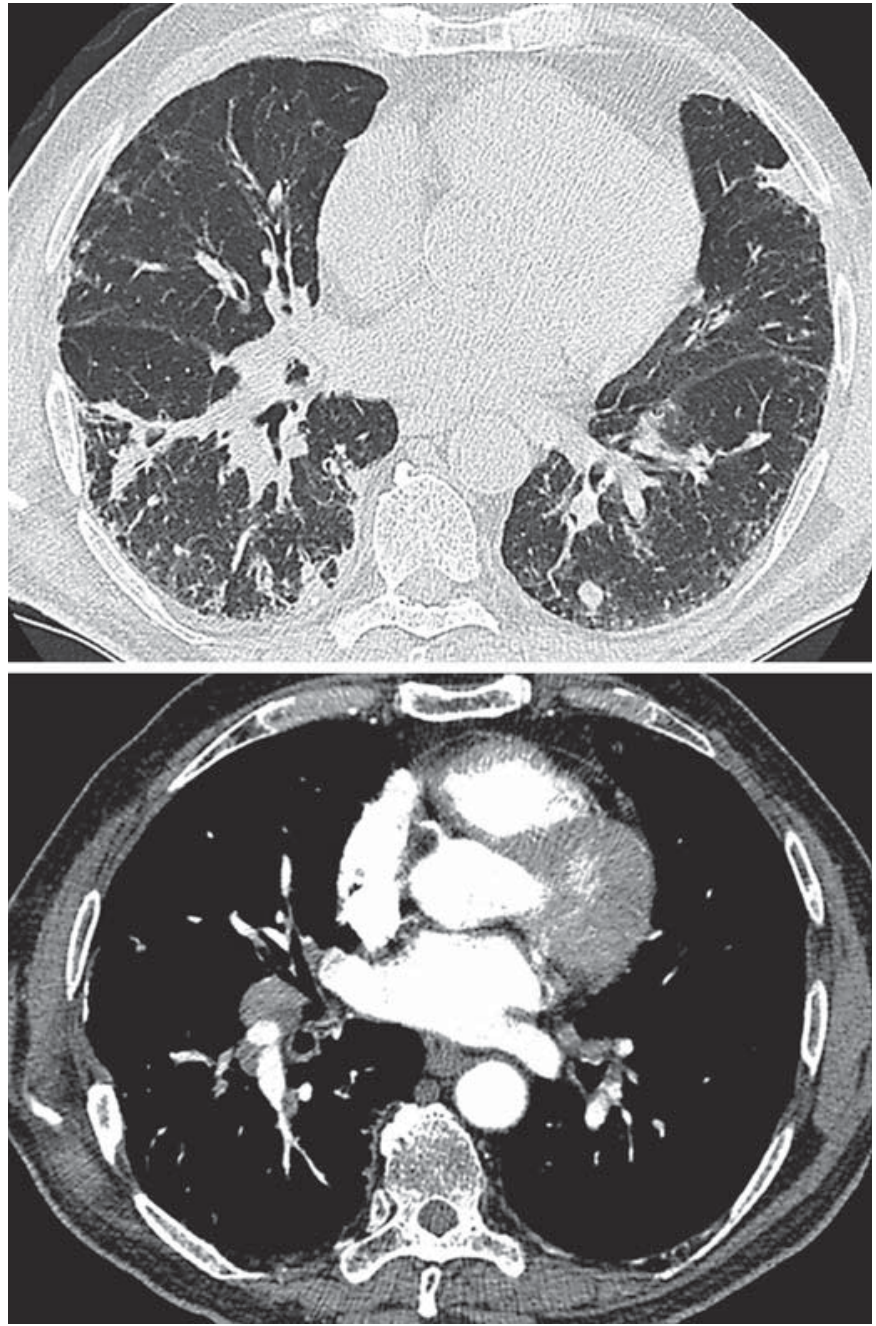

Fig. 2. Thoracic computed tomography of a patient with IgG4related lung disease showing thickening of bronchovascular bundles, interlobular septa, nodule and consolidation, reticulation, and asymmetrical hilar lymphadenopathy.

patients have normal serum IgG4 concentrations [67], but response to treatment in the case of active disease is better when serum IgG4 is increased [67]. High serum IgG4 levels may be seen in carcinomas and autoimmune diseases [98]. An increase in C-reactive protein or Krebs von den Lungen-6, low level of complement and antinuclear antibodies and/or rheumatoid factor positivity may be observed [76, 79, 85, 99]. Blood eosinophilia and elevated IgE level especially without atopy, suggest an IgG4$\mathrm{RD}$ process [87]. IgG4 and C-reactive protein levels are higher in patients with intrathoracic disease [85]. BAL in IgG4-RRD predominantly shows lymphocytosis with a normal CD4/CD8 ratio [75]. BAL total cell counts and

The Lung in Dysregulated States of Humoral Immunity lymphocyte rates are significantly lower with significantly more eosinophils, and cytokines characteristic of Th2 response than in sarcoidosis [90]. Histopathology combined with immunohistochemistry remains the cornerstone of diagnosis (Fig. 3). Even though needle biopsy has been generally considered inadequate for confirming IgG4-RD diagnosis [100], the diagnostic yield of transthoracic core needle biopsy reaches $2 / 3$ of the cases [84]. However, surgical lung biopsy is often needed [84]. An international pathological consensus statement defined IgG4-RD diagnosis on the combined presence of a characteristic histopathological pattern and increased numbers of IgG4 ${ }^{+}$plasma cells [101] (Fig. 3). The 3 main pathological features are dense lymphoplasmacytic infiltration, obliterative phlebitis, and a storiform fibrosis pattern defined as radially arranged collagen fibers that seem to weave through the tissue $[64,101]$, with occasional eosinophilic infiltration [86]. Lesions may have a lymphatic distribution [75, 102]. Epithelioid cell granulomas and prominent neutrophilic infiltrate are considered inconsistent with IgG4-RD diagnosis [101]. Some variants make the diagnosis more difficult $[77,86,101]$ : neutrophil aggregates in bronchioloalveolar spaces, multinucleated giant cells [86], obliterative arteritis rather than phlebitis [86], absence of storiform fibrosis [101]. After a long course, fibrosis may predominate, making histological features less specific [64]. Pleura may be severely thickened by diffuse sclerosing inflammation [86]. The IgG4 immunostaining is essential, showing a polyclonal lymphoplasmacytic infiltration rich in $\operatorname{IgG} 4^{+}$plasma cells. Diagnosis requires an increased $\operatorname{IgG} 4^{+} / \mathrm{IgG}$ ratio over $40 \%$ with an elevated number of IgG4 $4^{+}$plasma cell/high power field in the biopsy [101]. IgG4 ${ }^{+}$plasma cells are diffusely distributed within nodular lesions in the alveolar interstitium, bronchovascular bundles, interlobular septa, and pleura $[86,101]$. Focal aggregations are atypical [64]. The appropriate cut-off for IgG4 plasma cell counts may vary from organ to organ and according to the importance of fibrosis [101]. IgG4-RRD should not be diagnosed only based on IgG4 plasma cell accumulation as it can also occur in a large wide of inflammatory conditions (Castleman disease, collagen disease-related lung disease, vasculitis, Rosai-Dorfman disease), lymphomas, or lung cancer $[79,101,102]$. Association with other patterns has been reported including usual interstitial pneumonia, nonspecific interstitial pneumonia, organizing pneumonia, and granulomatosis with polyangiitis [75, 103-105]. In summary, the most accurate assessment of IgG4-RD is based on a full clinical history, physical examination, laboratory investigations, and appropriate imaging studies.

Respiration 2017;94:389-404 DOI: $10.1159 / 000480297$ 

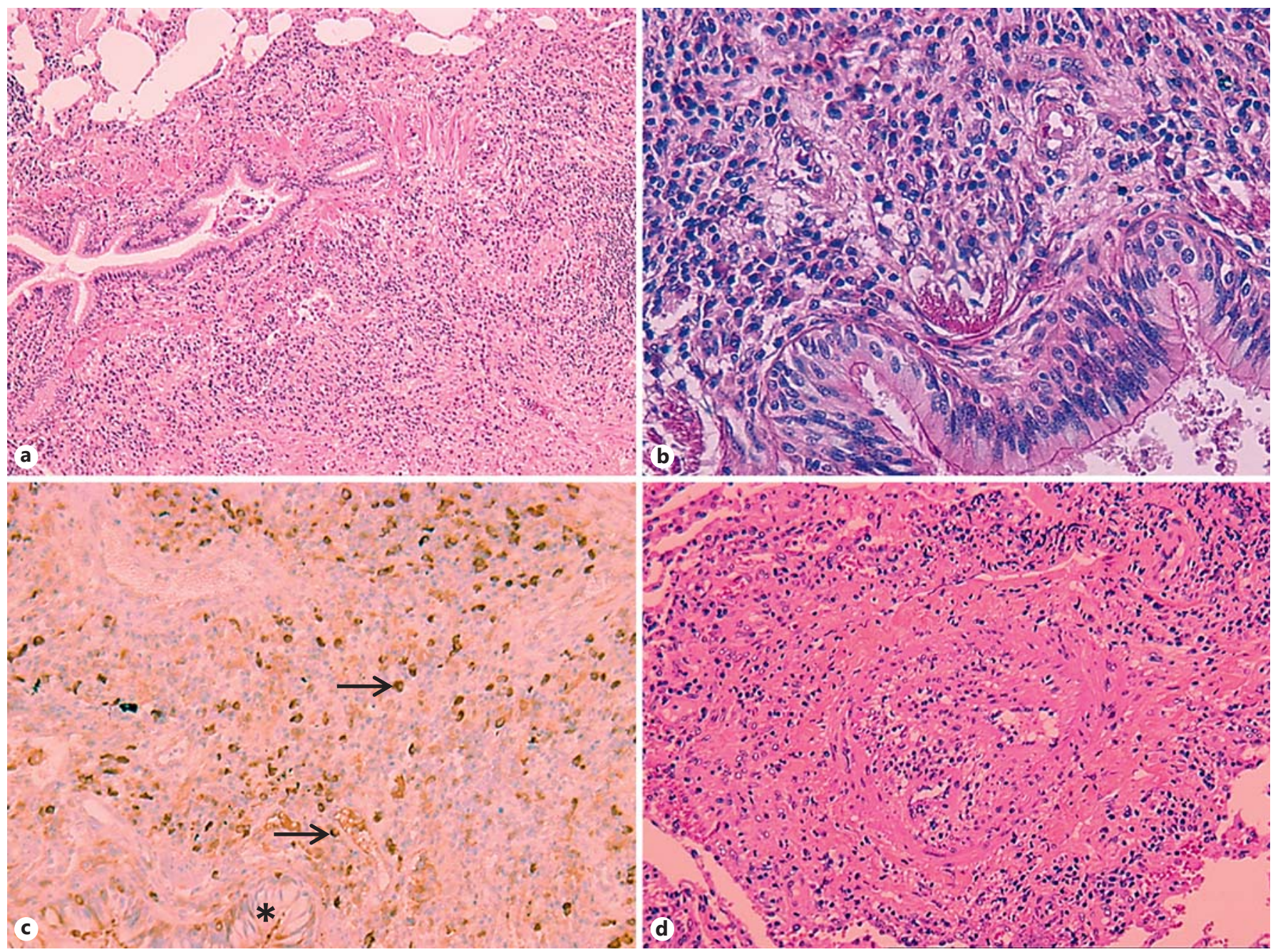

Fig. 3. Hematoxylin-eosin stain (a, b, d) and IgG4 immunostaining (c) of a surgical lung biopsy of a pulmonary nodule from a patient presenting nodules, mediastinal adenopathy, and interstitial pneumonitis on chest computed tomography. a Low power field $(\times 50)$ showing a dense inflammatory infiltrate in a peribronchiolar area. b Plasma cell infiltration is observed around a bronchiole $(\times 100)$. c IgG4-positive plasma cells (arrows) surrounding a bronchiole $\left(^{*}\right)(\times 100)$. d Mononuclear cell infiltration surrounding a pulmonary artery with plexiform lesions.

Confirmation by biopsy is strongly recommended to exclude malignancies and other IgG4-RD mimics [100]. Comprehensive diagnostic criteria for IgG4-RD have been proposed in Japan for nonspecialists [106], and recently Matsui et al. [79] adapted these criteria for specific diagnosis of IgG4-RRD (Table 2).

An international consensus for IgG4-RD treatment has recently been published [100]. Patients with either symptomatic active IgG4-RD or asymptomatic patients with specific risks require to be treated to prevent irreversible sequelae in the biliary tree, kidney, aorta, mediastinum, retroperitoneum, and mesentery. Emergency treatment is needed for those at risk for aortic dissection, ureteral obstruction, renal failure, common bile duct compression, visual acuity reduction, nerve palsies, and pericardial complications [100]. Surveillance is advocated in asymptomatic patients with localized disease without risky outcome [107]. Glucocorticoids are given first to obtain remission. In a multicenter phase II prospective trial, $0.6 \mathrm{mg} / \mathrm{kg} / \mathrm{day}$ prednisolone was administrated initially, then reduced by $10 \%$ every 2 weeks followed by a maintenance dose, allowing a complete remission in $66 \%$ of patients at 1 year [108]. A low maintenance dose of prednisone (5-10 $\mathrm{mg} /$ day) is administered to some pa-
Uzunhan/Jeny/Kambouchner/Didier/ Bouvry/Nunes/Bernaudin/Valeyre 
tients and recommended for up to 3 years according to some clinicians [109]. Glucocorticoids combined with steroid-sparing immunosuppressive agents (cyclophosphamide $[84,85]$, mycophenolate mofetil [110], azathioprine, methotrexate) may be advised in some contexts. For relapse after a prior successful remission, a retreatment with glucocorticoids is indicated and, for remission maintenance, a steroid-sparing agent is to be considered [100]. Rituximab [111] appears effective and may be used if there is a contraindication to corticosteroid or in case of corticoresistance, or as a steroid-sparing agent. In one open-label trial, $97 \%$ of patients under rituximab responded to treatment response and $47 \%$ were in complete remission at 6 months [111]. Corticosteroids trigger a good and rapid response in IgG4-RRD with improvement after 2 weeks to several months [64, 112]. Spontaneous improvement has occasionally been reported in the lung $[75,85]$. ILD, lymphadenopathy, and bronchial thickening are sensitive to corticosteroids and immunosuppressive treatments, while one-third of solitary nodular lesions are not [85]. In contrast to idiopathic conditions, fibrosing mediastinitis, $\mathrm{PH}$, even a usual interstitial pneumonia pattern observed on CT or obliterans bronchiolitis related to IgG4 respond well to treatment $[92,96$, $105,113]$. The long-term outcome and prognosis are not yet known. Death from respiratory failure has been reported [84]. A history of relapse appears to be a strong predictor of further relapse, as well as elevated levels of serum IgG4, IgE, and eosinophils [67]. A poor response should raise the possibility of an alternative diagnosis, particularly cancer $[64,108]$.

\section{Respiratory Amyloidosis}

Amyloidosis is characterized by extracellular aggregates of insoluble misfolded fibrils leading to organ dysfunction [114]. In the consensus terminology, A designates "amyloidosis" followed by indicators of the specific protein precursor: IgG-associated AL amyloidosis (L: light chains), serum amyloid A amyloidosis (AA) associated with chronic inflammatory diseases, transthyretin amyloidosis (ATTR) with accumulation of transthyretin (mutant in hereditary form, or acquired in senile form), and $\beta_{2}$-microglobulin accumulation amyloidosis (AB2M) in dialyzed patients [114]. More frequently primitive, amyloidosis may be associated with another disease. AL amyloidosis (immunoglobulinic or "primary" amyloidosis) is by far the leading type of amyloidosis in the respiratory system, while AA amyloidosis is much rarer $[115,116]$.

The Lung in Dysregulated States of Humoral Immunity
Table 2. Diagnostic criteria for IgG4-related respiratory disease (adapted from Ryu et al. [78])
A Diagnostic criteria
I Chest imaging
Imaging findings include any of the following intrathoracic lesions: hilar/mediastinal lymphadenopathy, bronchial wall/ bronchovascular bundle thickening, interlobular septal wall thickening, nodular shadow, infiltrative shadow, pleural thickening and/or effusion

II Serology

Elevated serum IgG4 concentration of $\geq 135 \mathrm{mg} / \mathrm{dL}$

III Histology

Two or more of the following items are required for intrathoracic tissues analysis:

a: $\geq 3$ items; b: 2 items

1 Marked lymphoplasmacytic cell infiltration of peribronchovascular bundles, interlobular septa, and/ or pleura

2 IgG4 $4^{+} /$IgG plasma cell ratio $>40 \%$ and/or $>10 \mathrm{IgG} 4^{+}$ cells/high power field

3 Obliterative phlebitis or arteritis

4 Storiform fibrosis or proliferation of spindle-shaped cells around infiltrating lymphocytes

IV Other organ involvement

Presence of extrathoracic lesions satisfying the criteria of IgG4-related disease as sclerosing dacryoadenitis/ sialadenitis, auto immune pancreatitis, sclerosing cholangitis, IgG4-related kidney disease, and retroperitoneal fibrosis

V. Biological test results

Hypocomplementemia

B Diagnosis

1 Definite: I + II + IIIa, or I + II + IIIb + IV

Definite (histological): I + all the 4 items of III

2 Probable: I + II + IV, or I + II + IIIb + V

3 Possible: I + II + IIIb

C Differential diagnosis

It is important to differentiate IgG4-related respiratory disease from diseases with similar features: Castleman disease (plasma cell type), collagen disease-related lung disease, granulomatosis with polyangiitis (Wegener's), eosinophilic granulomatosis with polyangiitis (ChurgStrauss syndrome), sarcoidosis, respiratory organ infection, Rosai-Dorfman disease, inflammatory myofibroblastic tumor, malignant lymphoma, lung cancer

$\mathrm{AL}$ amyloidosis is most commonly found in a context of plasma cell disorder, while $5 \%$ concern B-cell lymphoma. All structures of the respiratory system may be affected: airways, parenchyma, pleura, intrathoracic lymph nodes, and vessels $[116,117]$. Lesion distribution varies accord-

Respiration 2017;94:389-404 
Table 3. Respiratory tract amyloidosis patterns

\begin{tabular}{llll}
\hline & Tracheobronchial amyloidosis & Parenchymal amyloidosis & Diffuse interstitial amyloidosis \\
\hline Main subtype & Localized AL & Localized AL & Systemic AL \\
\hline Phenotype & Obstructive bronchial disease & $\begin{array}{l}\text { Nodular lesions } \pm \text { calcifications } \\
\text { Cystic lesions }\end{array}$ & $\begin{array}{l}\text { Alveolar-septal involvement } \\
\text { Thickening of interalveolar septas } \\
\text { Parenchymal nodules }\end{array}$ \\
\hline Underlying disease & No & Low-grade lymphoma & $\begin{array}{l}\text { Low-grade lymphoma } \\
\text { Multiple myeloma } \\
\text { Connective tissue disease }\end{array}$ \\
\hline
\end{tabular}

ing to the localized or nonlocalized nature of amyloidosis and its subtype (Table 3) [118].

Systemic amyloidosis most often affects lung parenchyma, lymph nodes, and pleura, and may be associated with cardiac or renal involvement. Localized amyloidosis includes tracheobronchial involvement and isolated parenchymal involvement with nodular, cystic, and diffuse interstitial manifestations.

The diagnosis of amyloidosis relies on histopathology [114]. Routine staining shows extracellular deposition of amorphous eosinophilic material especially around vessels. After Congo red staining, a red appearance is observed in normal light and apple-green birefringence under crosspolarized light. Amyloid deposits may show a red-violet metachromasia with violet crystal and a strong fluorescence with thioflavin under UV light [114]. In contrast to the granular deposits of light chains, amyloid deposits are ultrastructurally characterized by 8 - to $10-\mathrm{nm}$ diameter fibrils [114]. Immunodetection of kappa/lambda light chains, serum amyloid A, transthyretin, and apolipoprotein $\mathrm{A} 1$ is helpful. Negative immunostaining for SAA and TTR exclude AA and TTR types, but negative immunostaining for kappa and lambda chains may occur in up to $60 \%$ of AL type [119]. Mass spectrometry is becoming the gold standard for typing amyloid deposits [120].

Tracheobronchial amyloidosis (TBA) accounted for $1.1 \%$ of cases in a large series of patients with amyloidosis [121], but up to $29-53 \%$ of cases of respiratory amyloidosis [121-128]. The mean age is $48-57$ without gender predilection [8-15]. TBA may be due to monoclonal gammopathy [129] with or without systemic amyloidosis [130-132]. Light-chain deposits of amyloid may be due to focal clonal plasma cell proliferation responsible for local amyloid production $[133,134]$. TBA caused by AL or AA systemic amyloidosis is rare $[124,135,136]$. Associated mediastino-hilar lymphadenopathy may suggest systemic amyloidosis [129].
Bronchoscopy in TBA reveals multifocal submucosal plaques (85\%) (Fig. 4) and pseudotumor masses (15\%) [128]. Usually isolated, the amyloid tumor-like masses are not obstructive, and the diagnosis is often fortuitous (Fig. 4). Conversely, multifocal submucosal plaques with submucosal white-greyish deposits reduce airway lumen and are usually symptomatic - cough, hemoptysis, dyspnea, hoarseness, or recurrent pneumonia; shortness of breath may be the main symptom with sometimes stridor, wheezing, or whistling [121-123, 126, 128, 135-139]. Often mistaken for asthma or COPD, the correct diagnosis may be delayed for many years. Lesions may be exclusively laryngeal $(12.5 \%)$, tracheal (3\%), laryngotracheal (28\%), tracheobronchial (44\%), or extend to the entire respiratory tract (12.5\%) [139]. Compressive amyloid goiter has been reported [140]. PFTs show airflow obstruction or a characteristic upper airway inspiratory obstruction.

Chest radiography unveils atelectasis, possible calcifications, or narrowing of the tracheal lumen [141, 142]. Lung CT may show focal or diffuse circumferential tracheal and bronchial thickening with luminal narrowing, atelectasis, and/or localized bronchiectasis [121, 142]. Calcifications with "ossification of submucosal nodules" may be observed. Three-dimensional reconstruction allows precise lesion mapping [143]. Narrowband imaging bronchoscopy might be more sensitive for early diagnosis [144].

Surgical excision of the lesions is now abandoned due to a high risk of hemorrhage. Endoscopic debulking yields satisfactory long-term results. Nd-YAG laser, argon plasma coagulation, freezing, resection, clamping, microwaving, high-frequency electrocautery, and stent implantation under rigid bronchoscopy may be used [145]. Repeated procedures ensure good bronchial permeability [146]. In limited series, targeted external radiotherapy (20 Gy in 10 fractions) led to clinical improvement within a

Uzunhan/Jeny/Kambouchner/Didier/ Bouvry/Nunes/Bernaudin/Valeyre 


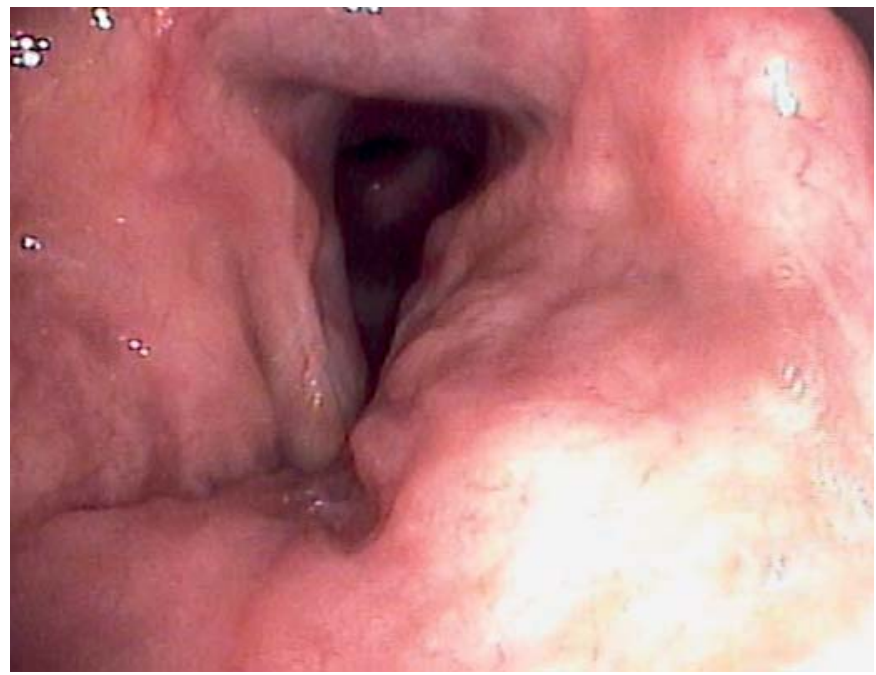

Fig. 4. Endoscopic presentation of tracheobronchial amyloidosis: evidence of multifocal submucosal plaques.

period of 1 month to 1 year [147, 148] with long-term improvement of spirometry [149]. Combined endoscopic procedures may be followed by radiotherapy [150]. Interesting results with colchicine have been reported [151]. TBA outcome may be marked by recurrent pneumonia and progressive obstructive respiratory failure. In contrast to other localized forms of amyloidosis, TBA has a bad prognosis with an estimated 5-year survival of only 30-50\% [142].

Nodular and cystic amyloidosis accounts for $44-58 \%$ of respiratory amyloidosis [122, 123, 126, 128, 152-154]. Cystic lesions are uncommon and often associated with nodules [155]. The mean age at diagnosis is 67 years, and the male/female ratio is $3: 2[116,126,156]$.

Mostly discovered incidentally on thoracic imaging or autopsy, nodular amyloidosis may also be revealed by cough, dyspnea, or hemoptysis. Amyloidosis should be considered in the gamut of multicystic lung diseases among biopsy-proven pulmonary amyloidosis as a cystic lung pattern is observed in $11 \%$ of cases [155].

Nodules may be single (52\%) or multiple (48\%), with various shapes and sizes [157]. Spots of calcification/ossification are found in $26-50 \%[117,122]$ and cavitations in $10 \%$ of cases $[117,122,126]$. Peripheral subpleural localization is common, particularly in the lower lobes. Multiple cystic lesions may be associated [158]. Cysts tend to be round or lobulated, multiple and bilateral, of small to moderate size. Most are thin-walled with a lower lobe predominance [155]. In $81 \%$ of cases, cysts are associated with nodules, some of which are partially calcified

The Lung in Dysregulated States of Humoral Immunity
[155]. An increased ${ }^{18 \mathrm{~F}} \mathrm{FDG}$ uptake [159-162] is frequent [163] with reduced activity on the 2 -h delayed images, in contrast to malignant lesions [164]. ${ }^{123}$ I-serum amyloid P component scintigraphy may be useful to document visceral uptake [165].

Tissue for histopathology may be obtained by transbronchial biopsy or CT-guided needle biopsy, but surgical lung biopsy is considered more suitable for amyloid deposit analysis and detection of a clonal B cell proliferation $[155,161,164,166]$.

Nodular and cystic pulmonary amyloidosis may be the only localization of amyloidosis resulting from an underlying lymphoproliferative disorder such as marginal zone lymphoma of MALT lymphoma [167]. AL amyloidosis predominates in cystic lung amyloidosis [155]. It is mainly a localized pulmonary amyloidosis (76\%) and less often associated with systemic amyloidosis (19\%) [155]. Fiftyseven percent of patients present an associated connective tissue disease (CTD), generally Sjögren syndrome $[155,168]$. Localized amyloidosis must be distinguished from B-cell lymphoproliferation with peritumoral amyloidosis [169]. Lung and soft tissues are more commonly affected by both entities [169]. Peritumoral amyloidosis involves a single organ, either lung or soft tissue, associated with MALT lymphoma and trace or undetectable IgM paraprotein [169]. Systemic amyloidosis involves several organs with high IgM paraprotein and underlying Waldenström macroglobulinemia [170-172]. While usually AL, localized parenchymal amyloidosis may be AA, wild-type ATTR, mixed AB2M/AL amyloidosis and, exceptionally, senile [116].

Localized pulmonary nodular amyloidosis is usually associated with a benign prognosis, rarely requiring treatment. Conservative excision may be curative with exceptional postoperative recurrences [173]. Fatal hemoptysis is a rare event [174]. Peritumoral amyloidosis is rarely progressive, despite the lack of appreciable response [158, $167,169]$. By contrast, shortened survival was reported in patients with IgM-related systemic amyloidosis as a complication of cardiac or renal involvement $[169,171,172]$. These observations justify comprehensive evaluation to distinguish peritumoral amyloidosis from systemic AL, as the therapeutic approach is different [175].

Interstitial amyloidosis with diffuse alveolar septal deposits may be part of a systemic process or limited to lungs, the latter being exceptional and severe [122, 125, 128]. The high prevalence of lung involvement in systemic AL amyloidosis contrasts with its low clinical impact $[124,126,152,176]$. Interstitial involvement is exceptionally due to AA amyloidosis $[115,177]$. While antemortem 


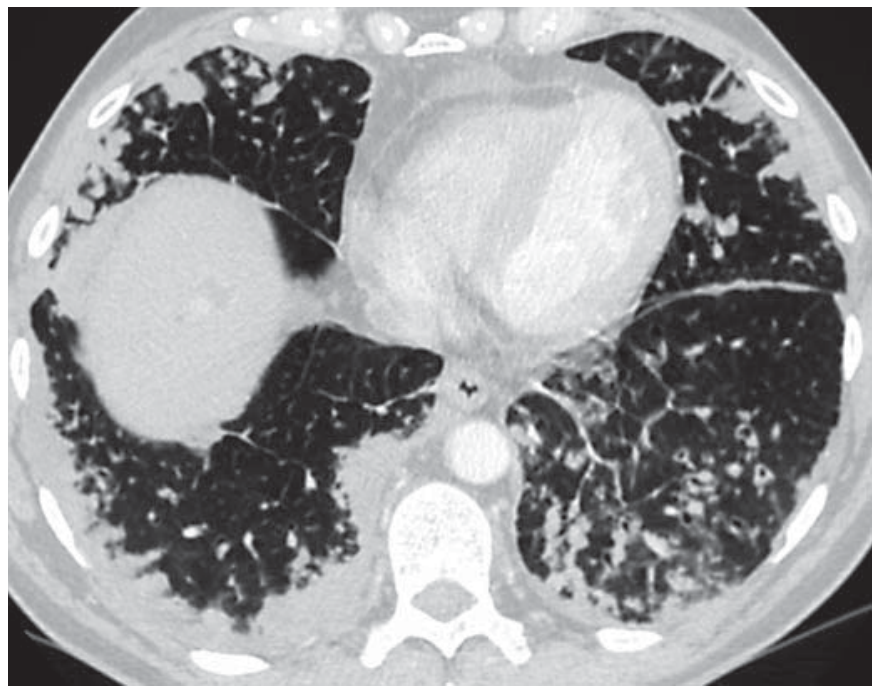

Fig. 5. Thoracic high-resolution computed tomography. Amyloidosis with diffuse interstitial lung disease: nodules, septal lines, consolidation, pleural nodules, and thickening.

diagnosis is rare [176], chest radiographs obtained within 1 year before death are abnormal in $91 \%$ of cases and chest CT in 97\%. Lung involvement in ATTR amyloidosis is always associated with cardiac amyloidosis [176].

Interstitial amyloidosis may alter alveolar-capillary gas exchange leading to fatal respiratory failure in $50 \%$ of cases. Underlying condition may be a lymphoproliferative disorder or a CTD. IgM as IgG-related amyloidosis usually occurs in the setting of monoclonal disorders with a low tumor burden [171]. The diagnosis of lung involvement in AL amyloidosis $[118,178]$ relies on an interstitial pattern on CT and histopathology. Interstitial amyloidosis is more frequent in IgM amyloidosis mostly of kappa light chain [171, 179], while it represents a minority among all amyloidoses [180]. Most often (52\%), the underlying disease is a lymphoproliferation rather than myeloma [170].

CT shows diffuse irregular lines, thickening of interlobular septa with possible honeycombing and bronchiectasis (Fig. 5). Parenchymal nodules and/or cystic lesions and mediastino-hilar lymphadenopathy may be associated [141, 181]. Sometimes, a diffuse micronodular pattern may be observed [141, 182, 183]. Areas of septal thickening, predominantly peripheral and basal consolidation, patchy GGO and parenchymal micronodules are all compatible with interstitial amyloidosis [184] (Fig. 5).

Pulmonary progression is generally slow in CTD-associated amyloidosis, but may be rapid in systemic amyloidosis, making it the second cause of death after cardiac involvement [176]. The main respiratory causes of death include pneumonia, aspiration, and pulmonary embolism, but rarely amyloidosis itself [176]. In the largest series of IgM-related amyloidosis, the median overall survival was 47.9 months. Patients free of bone marrow clonal infiltrate have a better survival (54 months) than those with lymphoid (44 months) or plasma cell (23 months) infiltrate. A worse response to novel treatment agents is observed in IgM compared to IgA and/or IgG AL amyloidosis [170].

Pulmonary vascular amyloid deposition is frequent, particularly in systemic amyloidosis with cardiac involvement. Mostly asymptomatic, it may rarely be responsible for hemoptysis, hemothorax, or even intra-alveolar hemorrhage with sometimes fatal hemorrhagic diathesis [174, 185]. PH during AL amyloidosis is mostly secondary to restrictive amyloid cardiomyopathy. Exceptional cases of isolated precapillary PH have been described [186-190].

Pleural amyloidosis, almost exclusively of the AL type, is very rare, representing only $5-10 \%$ of respiratory amyloidosis [121]. Pleural effusion ranges from transudate in relation to cardiac or renal involvement or dysthyroidism to exudates associated with specific pleural amyloid involvement. Chylothorax, either related or not to compressive intrathoracic lymphadenopathy, has been reported [191]. Imaging may show pleural thickening and calcifications [192]. Pleural effusion confers a bad prognosis with an estimated median survival of 1.6 months in the case of cardiac amyloidosis [191].

Mediastinal and hilar lymph nodes may be calcified (in eggshell) and often associated with parenchymal or TBA [193]. In systemic amyloidosis, enlarged mediastinal lymph nodes may be localized and isolated in $17 \%$ of cases or more frequently associated with pulmonary involvement $[183,194]$. Primary AL amyloidosis may be diagnosed on lymphadenopathy by endobronchial ultrasound-guided transbronchial needle aspiration cytology (EBUS) [195-198].

\section{Pulmonary Light-Chain Deposition Disease}

Historically described in the kidney, light-chain deposition disease (LCDD) may exceptionally affect the lung [199]. An amorphous eosinophilic material, not stained by Congo red, is distributed in the interstitial space along the basal membrane and corresponds to the deposition of monotypic (most often kappa) light chains [199]. Kidney, heart, and digestive tract are by far more often involved. Mostly associated with lymphoproliferation, LCDD may
398

Respiration 2017;94:389-404

DOI: $10.1159 / 000480297$
Uzunhan/Jeny/Kambouchner/Didier/ Bouvry/Nunes/Bernaudin/Valeyre 
be associated with autoimmune conditions or may be idiopathic. Isolated pulmonary LCDD is sparsely reported [156, 200-202]. Manifestations include nodular and diffuse interstitial patterns [203]. Cystic forms of LCDD have recently been described $[201,203]$. Patient age ranges from 33 to 78 years, with a mean of 60.7 years and a male/female ratio of 1:2. The differential diagnoses include other multicystic lung diseases [204]. Bronchial light chain deposits have also been associated with bronchiectasis or tracheomegaly $[181,205,206]$. Deposits may be detected on labial biopsies [201]. End-stage multiple cystic lung disease requiring lung transplantation has been described [201]. Most commonly, LCDD is associated with myeloma, Waldenström macroglobulinemia, chronic lymphocytic leukemia or other malignant B-cell lymphoproliferation [203]. Plasma B cell dyscrasia should therefore be systematically screened in serum, urine, or by bone marrow aspiration. In one-third of cases, failure to detect a systemic B-cell clone suggests a primary in situ pulmonary plasma cell proliferation. Combined with clinical and biological data, the data of Colombat et al. [206] support an antigen-driven primary pulmonary lymphoproliferative disorder. Pulmonary LCDD is an indolent or slowly progressive disease [203]. No recurrence after a 4-year follow-up was observed after lung transplantation [201, 207]. Unlike localized disease, treatment of systemic LCDD aims at reducing the serum free light chain level to limit lung deposits. Optimal treatment remains to be defined. Chemotherapy can be associated with peripheral blood stem cell transplantation [207].

\section{Other Diseases due to Nonamyloid IgGs}

\section{Heavy-Chain Deposition Disease}

Heavy-chain deposition disease confined to the respiratory tract is extremely rare consisting of parenchymal masses and enlarged lymph nodes [208].

\section{Crystal Globulinemia}

Due to unknown mechanisms, crystal formation by monoclonal Ig, particularly kappa light chains, is virtually possible in every tissue. Pulmonary involvement may be interstitial or nodular with pleura more rarely involved. Lesions are characterized by infiltration of histiocytic cells containing crystal deposits [209-212]. The underlying lymphoid $\mathrm{B}$ proliferation may remain occult [210].

\section{Cryoglobulinemia and Cryofibrinogenemia}

During AL amyloidosis or other IgG deposition diseases, the involved monoclonal Ig may be difficult to detect because of cold-induced precipitation of the protein (type I cryoglobulin). Thus, physicians should carefully look for a cryoglobulin and type it. The clinical presentation, mostly dermatologic, is related to the vascular and capillary tropism of the cryoprecipitates. Its respiratory manifestations may be an organized pneumonia particularly with vascular involvement with abundant siderophages [213]. Cryofibrinogen may be distinguished from cryoglobulin according to tissue granulomatous reaction in the former [214].

\section{References}

1 Chapel H, Lucas M, Lee M, Bjorkander J, Webster D, Grimbacher B, et al: Common variable immunodeficiency disorders: division into distinct clinical phenotypes. Blood 2008;112:277-286.

-2 Oksenhendler E, Gérard L, Fieschi C, Malphettes M, Mouillot G, Jaussaud R, et al: Infections in 252 patients with common variable immunodeficiency. Clin Infect Dis 2008; 46:1547-1554.

-3 Ameratunga R, Woon S-T, Gillis D, Koopmans W, Steele R: New diagnostic criteria for common variable immune deficiency (CVID), which may assist with decisions to treat with intravenous or subcutaneous immunoglobulin. Clin Exp Immunol 2013;174: 203-211.

-4 Cunningham-Rundles C, Maglione PJ: Common variable immunodeficiency. J Allergy Clin Immunol 2012;129:1425-1426.e3.

The Lung in Dysregulated States of Humoral Immunity
5 ESID Registry - Working Definitions for Clinical Diagnosis of PID. http://esid.org/ Working-Parties/Registry/Diagnosis-criteria.

-6 Bertinchamp R, Gérard L, Boutboul D, Malphettes M, Fieschi C, Oksenhendler E, et al: Exclusion of patients with a severe T-cell defect improves the definition of common variable immunodeficiency. J Allergy Clin Immunol Pract 2016;4:1147-1157.

7 Bonilla FA, Barlan I, Chapel H, Costa-Carvalho BT, Cunningham-Rundles C, de la Morena MT, et al: International Consensus Document (ICON): Common Variable Immunodeficiency Disorders. J Allergy Clin Immunol Pract 2016;4:38-59.

-8 International Union of Immunological Societies Expert Committee on Primary Immunodeficiencies, Notarangelo LD, Fischer A, Geha RS, Casanova J-L, Chapel H, et al: Primary immunodeficiencies: 2009 update. J Allergy Clin Immunol 2009;124:1161-1178.
\$9 Chapel H, Cunningham-Rundles C: Update in understanding common variable immunodeficiency disorders (CVIDs) and the management of patients with these conditions. $\mathrm{Br}$ J Haematol 2009;145:709-727.

10 Tseng C-W, Lai K-L, Chen D-Y, Lin C-H, Chen $\mathrm{H}-\mathrm{H}$ : The incidence and prevalence of common variable immunodeficiency disease in Taiwan, a population-based study. PLoS One 2015;10:e140473.

-11 Gathmann B, Mahlaoui N, CEREDIH, Gérard L, Oksenhendler E, Warnatz $\mathrm{K}$, et al: Clinical picture and treatment of 2,212 patients with common variable immunodeficiency. J Allergy Clin Immunol 2014;134: 116-126.

12 Hammarström L, Vorechovsky I, Webster D: Selective IgA deficiency (SIgAD) and common variable immunodeficiency (CVID). Clin Exp Immunol 2000;120:225-231. 
13 Cunningham-Rundles C, Bodian C: Common variable immunodeficiency: clinical and immunological features of 248 patients. Clin Immunol 1999;92:34-48.

14 Finck A, Van der Meer JWM, Schäffer AA, Pfannstiel J, Fieschi C, Plebani A, et al: Linkage of autosomal-dominant common variable immunodeficiency to chromosome 4q. Eur J Hum Genet 2006;14:867-875.

15 Wehr C, Kivioja T, Schmitt C, Ferry B, Witte T, Eren E, et al: The EUROclass trial: defining subgroups in common variable immunodeficiency. Blood 2008;111:77-85.

-16 Resnick ES, Moshier EL, Godbold JH, Cunningham-Rundles C: Morbidity and mortality in common variable immune deficiency over 4 decades. Blood 2012;119:1650-1657.

-17 Boileau J, Mouillot G, Gérard L, Carmagnat M, Rabian C, Oksenhendler E, et al: Autoimmunity in common variable immunodeficiency: correlation with lymphocyte phenotype in the French DEFI study. J Autoimmun 2011;36:25-32.

18 Maglione PJ: Autoimmune and lymphoproliferative complications of common variable immunodeficiency. Curr Allergy Asthma Rep 2016;16:19.

-19 Quinti I, Di Pietro C, Martini H, Pesce AM, Lombardi F, Baumghartner M, et al: Health related quality of life in common variable immunodeficiency. Yonsei Med J 2012;53:603610.

-20 Barker AF: Bronchiectasis. N Engl J Med 2002;346:1383-1393.

-21 Maglione PJ, Overbey JR, Radigan L, Bagiella E, Cunningham-Rundles C: Pulmonary radiologic findings in CVID: clinical and immunological correlations. Ann Allergy Asthma Immunol 2014;113:452-459.

-22 Gregersen S, Aaløkken TM, Mynarek G, Fevang $\mathrm{B}$, Holm AM, Ueland T, et al: Development of pulmonary abnormalities in patients with common variable immunodeficiency: associations with clinical and immunologic factors. Ann Allergy Asthma Immunol 2010; 104:503-510.

-23 Fevang B, Mollnes TE, Holm AM, Ueland T, Heggelund L, Damås JK, et al: Common variable immunodeficiency and the complement system; low mannose-binding lectin levels are associated with bronchiectasis. Clin Exp Immunol 2005; 142:576-584.

-24 Obregon RG, Lynch DA, Kaske T, Newell JD, Kirkpatrick $\mathrm{CH}$ : Radiologic findings of adult primary immunodeficiency disorders. Contribution of CT. Chest 1994;106:490-495.

- 25 Curtin JJ, Webster AD, Farrant J, Katz D: Bronchiectasis in hypogammaglobulinaemia - a computed tomography assessment. Clin Radiol 1991;44:82-84.

26 Welsh EJ, Evans DJ, Fowler SJ, Spencer S: Interventions for bronchiectasis: an overview of Cochrane systematic reviews. Cochrane Database Syst Rev 2015;CD010337.
27 Wong C, Jayaram L, Karalus N, Eaton T, Tong $\mathrm{C}$, Hockey $\mathrm{H}$, et al: Azithromycin for prevention of exacerbations in non-cystic fibrosis bronchiectasis (EMBRACE): a randomised, double-blind, placebo-controlled trial. Lancet 2012;380:660-667.

28 Junker AK, Bonilla FA, Sullivan KE: How to flee the flu. Clin Immunol 2004;112:219-220.

29 Lucas M, Hugh-Jones K, Welby A, Misbah S, Spaeth P, Chapel H: Immunomodulatory therapy to achieve maximum efficacy: doses, monitoring, compliance, and self-infusion at home. J Clin Immunol 2010;30(suppl 1):S84S89.

-30 Orange JS, Grossman WJ, Navickis RJ, Wilkes MM: Impact of trough IgG on pneumonia incidence in primary immunodeficiency: a meta-analysis of clinical studies. Clin Immunol 2010;137:21-30.

- 31 Quinti I, Soresina A, Guerra A, Rondelli R, Spadaro G, Agostini C, et al: Effectiveness of immunoglobulin replacement therapy on clinical outcome in patients with primary antibody deficiencies: results from a multicenter prospective cohort study. J Clin Immunol 2011;31:315-322.

32 Mannina A, Chung JH, Swigris JJ, Solomon JJ, Huie TJ, Yunt ZX, et al: Clinical predictors of a diagnosis of common variable immunodeficiency-related granulomatous-lymphocytic interstitial lung disease. Ann Am Thorac Soc 2016;13:1042-1049.

-33 Sweinberg SK, Wodell RA, Grodofsky MP, Greene JM, Conley ME: Retrospective analysis of the incidence of pulmonary disease in hypogammaglobulinemia. J Allergy Clin Immunol 1991;88:96-104.

34 Bates CA, Ellison MC, Lynch DA, Cool CD, Brown KK, Routes JM: Granulomatous-lymphocytic lung disease shortens survival in common variable immunodeficiency. J Allergy Clin Immunol 2004;114:415-421.

35 Wislez M, Sibony M, Naccache JM, Liote H, Carette MF, Oksenhendler E, et al: Organizing pneumonia related to common variable immunodeficiency. Case report and literature review. Respir Int Rev Thorac Dis 2000;67: 467-470.

36 Park JH, Levinson AI: Granulomatous-lymphocytic interstitial lung disease (GLILD) in common variable immunodeficiency (CVID). Clin Immunol 2010;134:97-103.

- 37 Bouvry D, Mouthon L, Brillet P-Y, Kambouchner M, Ducroix J-P, Cottin V, et al: Granulomatosis-associated common variable immunodeficiency disorder: a case-control study versus sarcoidosis. Eur Respir J 2013;41: 115-122.

38 Boursiquot J-N, Gérard L, Malphettes M, Fieschi C, Galicier L, Boutboul D, et al: Granulomatous disease in CVID: retrospective analysis of clinical characteristics and treatment efficacy in a cohort of 59 patients. J Clin Immunol 2013;33:84-95.

-39 Morimoto Y, Routes JM: Granulomatous disease in common variable immunodeficiency. Curr Allergy Asthma Rep 2005;5:370-375.
0 Schussler E, Beasley MB, Maglione PJ: Lung disease in primary antibody deficiencies. J Allergy Clin Immunol Pract 2016;4:1039-1052. 41 Chase NM, Verbsky JW, Hintermeyer MK, Waukau JK, Tomita-Mitchell A, Casper JT, et al: Use of combination chemotherapy for treatment of granulomatous and lymphocytic interstitial lung disease (GLILD) in patients with common variable immunodeficiency (CVID). J Clin Immunol 2013;33:30-39.

42 Ardeniz O, Cunningham-Rundles C: Granulomatous disease in common variable immunodeficiency. Clin Immunol 2009;133:198207.

43 Maarschalk-Ellerbroek LJ, de Jong PA, van Montfrans JM, Lammers JWJ, Bloem AC, Hoepelman AIM, et al: CT screening for pulmonary pathology in common variable immunodeficiency disorders and the correlation with clinical and immunological parameters. J Clin Immunol 2014;34:642-654.

44 Kollert F, Venhoff N, Goldacker S, Wehr C, Lützen N, Voll RE, et al: Bronchoalveolar lavage cytology resembles sarcoidosis in a subgroup of granulomatous CVID. Eur Respir J 2014;43:922-924.

45 Hartono S, Motosue MS, Khan S, Rodriguez V, Iyer VN, Divekar R, et al: Predictors of granulomatous lymphocytic interstitial lung disease in common variable immunodeficiency. Ann Allergy Asthma Immunol 2017; 118:614-620.

46 Verma N, Grimbacher B, Hurst JR: Lung disease in primary antibody deficiency. Lancet Respir Med 2015;3:651-660.

47 Jolles S, Carne E, Brouns M, El-Shanawany T, Williams P, Marshall C, et al: FDG PET-CT imaging of therapeutic response in granulomatous lymphocytic interstitial lung disease (GLILD) in common variable immunodeficiency (CVID). Clin Exp Immunol 2017;187: 138-145.

48 Milito C, Pulvirenti F, Serra G, Valente M, Pesce AM, Granata G, et al: Lung magnetic resonance imaging with diffusion weighted imaging provides regional structural as well as functional information without radiation exposure in primary antibody deficiencies. $\mathrm{J}$ Clin Immunol 2015;35:491-500.

49 Hampson FA, Chandra A, Screaton NJ, Condliffe A, Kumararatne DS, Exley AR, et al: Respiratory disease in common variable immunodeficiency and other primary immunodeficiency disorders. Clin Radiol 2012;67: 587-595.

50 Torigian DA, LaRosa DF, Levinson AI, Litzky LA, Miller WT: Granulomatous-lymphocytic interstitial lung disease associated with common variable immunodeficiency: CT findings. J Thorac Imaging 2008;23:162-169.

51 Maglione PJ, Overbey JR, Cunningham-Rundles C: Progression of common variable immunodeficiency interstitial lung disease accompanies distinct pulmonary and laboratory findings. J Allergy Clin Immunol Pract 2015;3:941-950. 
-52 Davies CW, Juniper MC, Gray W, Gleeson FV, Chapel HM, Davies RJ: Lymphoid interstitial pneumonitis associated with common variable hypogammaglobulinaemia treated with cyclosporin A. Thorax 2000;55:88-90.

53 Thatayatikom A, Thatayatikom S, White AJ: Infliximab treatment for severe granulomatous disease in common variable immunodeficiency: a case report and review of the literature. Ann Allergy Asthma Immunol 2005;95: 293-300.

54 Burton CM, Milman N, Andersen CB, Marquart $\mathrm{H}$, Iversen $\mathrm{M}$ : Common variable immune deficiency and lung transplantation. Scand J Infect Dis 2007;39:362-367.

55 Cunningham-Rundles C: How I treat common variable immune deficiency. Blood 2010; 116:7-15.

56 Chua I, Quinti I, Grimbacher B: Lymphoma in common variable immunodeficiency: interplay between immune dysregulation, infection and genetics. Curr Opin Hematol 2008; 15:368-374.

57 Roskin KM, Simchoni N, Liu Y, Lee J-Y, Seo $\mathrm{K}$, Hoh RA, et al: IgH sequences in common variable immune deficiency reveal altered $\mathrm{B}$ cell development and selection. Sci Transl Med 2015;7:302ra135.

- 58 Desar IME, Keuter M, Raemaekers JMM, Jansen JBMJ, van Krieken JHJ, van der Meer JWM: Extranodal marginal zone (MALT) lymphoma in common variable immunodeficiency. Neth J Med 2006;64:136-140.

-59 Reichenberger F, Wyser C, Gonon M, Cathomas G, Tamm M: Pulmonary mucosa-associated lymphoid tissue lymphoma in a patient with common variable immunodeficiency syndrome. Respir Int Rev Thorac Dis 2001;68: 109-112.

60 Cunningham-Rundles C, Cooper DL, Duffy TP, Strauchen J: Lymphomas of mucosal-associated lymphoid tissue in common variable immunodeficiency. Am J Hematol 2002;69: 171-178.

-61 Borie R, Wislez M, Antoine M, Copie-Bergman C, Thieblemont C, Cadranel J: Pulmonary mucosa-associated lymphoid tissue lymphoma revisited. Eur Respir J 2016;47:12441260.

-62 Hamano H, Kawa S, Horiuchi A, Unno H, Furuya $\mathrm{N}$, Akamatsu $\mathrm{T}$, et al: High serum IgG4 concentrations in patients with sclerosing pancreatitis. N Engl J Med 2001;344:732-738.

-63 Martínez-Valle F, Fernández-Codina A, Pinal-Fernández I, Orozco-Gálvez O, Vilardell-Tarrés M: IgG4-related disease: evidence from six recent cohorts. Autoimmun Rev 2017;16:168-172.

-64 Kamisawa T, Zen Y, Pillai S, Stone JH: IgG4related disease. Lancet 2015;385:1460-1471.

- 65 Stone JH, Khosroshahi A, Deshpande V, Chan JKC, Heathcote JG, Aalberse R, et al: Recommendations for the nomenclature of IgG4-related disease and its individual organ system manifestations. Arthritis Rheum 2012; 64:3061-3067.
66 Uchida K, Masamune A, Shimosegawa T, Okazaki K: Prevalence of IgG4-related disease in Japan based on nationwide survey in 2009. Int J Rheumatol 2012;2012:358371.

67 Wallace ZS, Deshpande V, Mattoo H, Mahajan VS, Kulikova M, Pillai S, et al: IgG4-related disease: clinical and laboratory features in one hundred twenty-five patients. Arthritis Rheumatol 2015;67:2466-2475.

68 Inoue D, Yoshida K, Yoneda N, Ozaki K, Matsubara T, Nagai K, et al: IgG4-related disease: dataset of 235 consecutive patients. Medicine (Baltimore) 2015;94:e680.

69 Della-Torre E, Lanzillotta M, Doglioni C: Immunology of IgG4-related disease. Clin Exp Immunol 2015;181:191-206.

70 Mattoo H, Mahajan VS, Maehara T, Deshpande V, Della-Torre E, Wallace ZS, et al: Clonal expansion of CD4(+) cytotoxic T lymphocytes in patients with IgG4-related disease. J Allergy Clin Immunol 2016;138:825838.

71 Bozzalla Cassione E, Stone JH: IgG4-related disease. Curr Opin Rheumatol 2017;29:223227.

72 Mattoo H, Mahajan VS, Della-Torre E, Sekigami Y, Carruthers M, Wallace ZS, et al: De novo oligoclonal expansions of circulating plasmablasts in active and relapsing IgG4-related disease. J Allergy Clin Immunol 2014; 134:679-687.

73 Aalberse RC, Stapel SO, Schuurman J, Rispens T: Immunoglobulin G4: an odd antibody. Clin Exp Allergy 2009;39:469-477.

-74 Muraki T, Hamano H, Ochi Y, Komatsu K, Komiyama Y, Arakura N, et al: Autoimmune pancreatitis and complement activation system. Pancreas 2006;32:16-21.

75 Matsui S, Hebisawa A, Sakai F, Yamamoto H, Terasaki Y, Kurihara Y, et al: Immunoglobulin G4-related lung disease: clinicoradiologi$\mathrm{cal}$ and pathological features. Respirology 2013;18:480-487.

-76 Taniguchi T, Ko M, Seko S, Nishida O, Inoue F, Kobayashi $\mathrm{H}$, et al: Interstitial pneumonia associated with autoimmune pancreatitis. Gut 2004;53:770.

-77 Inoue D, Zen Y, Abo H, Gabata T, Demachi $\mathrm{H}$, Kobayashi T, et al: Immunoglobulin G4related lung disease: CT findings with pathologic correlations. Radiology 2009;251:260270.

78 Ryu JH, Sekiguchi H, Yi ES: Pulmonary manifestations of immunoglobulin G4-related sclerosing disease. Eur Respir J 2012;39:180186.

79 Matsui S, Yamamoto H, Minamoto S, Waseda Y, Mishima M, Kubo K: Proposed diagnostic criteria for IgG4-related respiratory disease. Respir Investig 2016;54:130-132.

80 Sekiguchi H, Horie R, Kanai M, Suzuki R, Yi ES, Ryu JH: IgG4-related disease: retrospective analysis of one hundred sixty-six patients. Arthritis Rheumatol 2016;68:2290-2299.

81 Zen Y, Nakanuma Y: IgG4-related disease: a cross-sectional study of 114 cases. Am J Surg Pathol 2010;34:1812-1819.
2 Fernández-Codina A, Martínez-Valle F, Pinilla B, López C, DeTorres I, Solans-Laqué R, et al: IgG4-related disease: results from a multicenter Spanish registry. Medicine (Baltimore) 2015;94:e1275.

83 Lin W, Lu S, Chen H, Wu Q, Fei Y, Li M, et al: Clinical characteristics of immunoglobulin G4-related disease: a prospective study of 118 Chinese patients. Rheumatology 2015;54: 1982-1990.

84 Sun X, Liu H, Feng R, Peng M, Hou X, Wang $\mathrm{P}$, et al: Biopsy-proven IgG4-related lung disease. BMC Pulm Med 2016;16:20.

85 Fei Y, Shi J, Lin W, Chen Y, Feng R, Wu Q, et al: Intrathoracic involvements of immunoglobulin G4-related sclerosing disease. Medicine (Baltimore) 2015;94:e2150.

86 Zen Y, Inoue D, Kitao A, Onodera M, Abo H, Miyayama S, et al: IgG4-related lung and pleural disease: a clinicopathologic study of 21 cases. Am J Surg Pathol 2009;33:18861893.

87 Della Torre E, Mattoo H, Mahajan VS, Carruthers M, Pillai S, Stone JH: Prevalence of atopy, eosinophilia, and IgE elevation in IgG4-related disease. Allergy 2014;69:269272.

88 Hasegawa H, Nakamura Y, Kono M, Akamatsu T, Kaida Y, Inui N, et al: Bronchiolitis with IgG4-positive plasma cell infiltration in a patient with bronchial asthma (in Japanese). Nihon Kokyuki Gakkai Zasshi 2010;48:317321.

89 Matsui S, Sugiyama E, Taki H, Kawagishi Y, Miwa T, Hayashi R, et al: A case of bronchiolitis with IgG4-positive plasma cells infiltration associated with Mikulicz's disease and autoimmune pancreatitis (in Japanese). Nihon Kokyuki Gakkai Zasshi 2009;47:139144.

90 Yamamoto H, Yasuo M, Ichiyama T, Ushiki A, Hanaoka M, Hamano $\mathrm{H}$, et al: Cytokine profiles in the BAL fluid of IgG4-related respiratory disease compared with sarcoidosis. ERJ Open Res 2015;1.

91 Ito M, Yasuo M, Yamamoto H, Tsushima K, Tanabe T, Yokoyama T, et al: Central airway stenosis in a patient with autoimmune pancreatitis. Eur Respir J 2009;33:680-683.

92 Inoue M, Nose N, Nishikawa H, Takahashi M, Zen Y, Kawaguchi M: Successful treatment of sclerosing mediastinitis with a high serum IgG4 level. Gen Thorac Cardiovasc Surg 2007; 55:431-433.

93 Peikert T, Shrestha B, Aubry MC, Colby TV, Ryu JH, Sekiguchi H, et al: Histopathologic overlap between fibrosing mediastinitis and IgG4-related disease. Int J Rheumatol 2012; 2012:207056.

94 Atallah PC, Kassier A, Powers S: IgG4-related disease with effusive-constrictive pericarditis, tamponade, and hepatopathy: a novel triad. Int J Cardiol 2014;176:516-518.
The Lung in Dysregulated States of Humoral Immunity
Respiration 2017;94:389-404 DOI: $10.1159 / 000480297$ 
-95 Zhang J, Chen H, Ma Y, Xiao Y, Niu N, Lin $\mathrm{W}$, et al: Characterizing IgG4-related disease with ${ }^{18} \mathrm{~F}$-FDG PET/CT: a prospective cohort study. Eur J Nucl Med Mol Imaging 2014;41:1624-1634.

-96 Fukihara J, Kondoh Y, Taniguchi H, Kimura T, Kataoka K, Matsuda T, et al: Pulmonary hypertension associated with obliterative phlebitis in IgG4-related lung disease. Eur Respir J 2015;45:842-845.

-97 Carruthers MN, Khosroshahi A, Augustin T, Deshpande V, Stone JH: The diagnostic utility of serum IgG4 concentrations in IgG4-related disease. Ann Rheum Dis 2015; 74:14-18.

-98 Su Y, Sun W, Wang C, Wu X, Miao Y, Xiong $\mathrm{H}$, et al: Detection of serum IgG4 levels in patients with IgG4-related disease and other disorders. PLoS One 2015;10:e0124233.

-99 Kawano M, Mizushima I, Yamaguchi Y, Imai N, Nakashima H, Nishi S, et al: Immunohistochemical characteristics of IgG4-related tubulointerstitial nephritis: detailed analysis of 20 Japanese cases. Int J Rheumatol 2012;2012:609795.

100 Khosroshahi A, Wallace ZS, Crowe JL, Akamizu T, Azumi A, Carruthers MN, et al: International consensus guidance statement on the management and treatment of IgG4related disease. Arthritis Rheumatol 2015; 67:1688-1699.

101 Deshpande V, Zen Y, Chan JK, Yi EE, Sato $\mathrm{Y}$, Yoshino T, et al: Consensus statement on the pathology of IgG4-related disease. Mod Pathol 2012;25:1181-1192.

-102 Terasaki Y, Ikushima S, Matsui S, Hebisawa A, Ichimura Y, Izumi S, et al: Comparison of clinical and pathological features of lung lesions of systemic IgG4-related disease and idiopathic multicentric Castleman's disease. Histopathology 2017;70:1114-1124.

103 Della-Torre E, Lanzillotta M, Campochiaro C, Bozzalla E, Bozzolo E, Bandiera A, et al: Antineutrophil cytoplasmic antibody positivity in IgG4-related disease: a case report and review of the literature. Medicine (Baltimore) 2016;95:e4633.

104 Tanaka K, Nagata K, Tomii K, Imai Y: A case of isolated IgG4-related interstitial pneumonia: a new consideration for the cause of idiopathic nonspecific interstitial pneumonia. Chest 2012;142:228-230.

105 Schneider F, Veraldi KL, Levesque MC, et al: IgG4-related lung disease associated with usual interstitial pneumonia. Open Rheumatol J 2016;10:33-38.

106 Umehara H, Okazaki K, Masaki Y, Kawano M, Yamamoto M, Saeki T, et al: Comprehensive diagnostic criteria for IgG4-related disease (IgG4-RD), 2011. Mod Rheumatol 2012;22:21-30.

107 Della-Torre E, Stone JH: "How I manage" IgG4-related disease. J Clin Immunol 2016; 36:754-763.
108 Masaki Y, Matsui S, Saeki T, Tsuboi H, Hirata S, Izumi Y, et al: A multicenter phase II prospective clinical trial of glucocorticoid for patients with untreated IgG4-related disease. Mod Rheumatol 2016, Epub ahead of print.

109 Kamisawa T, Okazaki K, Kawa S, Ito T, Inui $\mathrm{K}$, Irie $\mathrm{H}$, et al: Amendment of the Japanese Consensus Guidelines for Autoimmune Pancreatitis, 2013 III. Treatment and prognosis of autoimmune pancreatitis. J Gastroenterol 2014;49:961-970.

110 Keenan JC, Miller E, Jessurun J, Allen T, Kim HJ: IgG4-related lung disease: a case series of 6 patients and review of the literature. Sarcoidosis Vasc Diffuse Lung Dis 2016;32: 360-367.

111 Carruthers MN, Topazian MD, Khosroshahi A, Witzig TE, Wallace ZS, Hart PA, et al: Rituximab for IgG4-related disease: a prospective, open-label trial. Ann Rheum Dis 2015;74:1171-1177.

112 Sandanayake NS, Church NI, Chapman MH, Johnson GJ, Dhar DK, Amin Z, et al: Presentation and management of posttreatment relapse in autoimmune pancreatitis/immunoglobulin G4-associated cholangitis. Clin Gastroenterol Hepatol 2009;7: 1089-1096.

113 Duvic C, Desrame J, Lévêque C, Nedelec G: Retroperitoneal fibrosis, sclerosing pancreatitis and bronchiolitis obliterans with organizing pneumonia. Nephrol Dial Transplant 2004;19:2397-2399.

114 Merlini G, Bellotti V: Molecular mechanisms of amyloidosis. N Engl J Med 2003; 349:583-596.

115 Planes C, Kleinknecht D, Brauner M, Battesti JP, Kemeny JL, Valeyre D: Diffuse interstitial lung disease due to AA amyloidosis. Thorax 1992;47:323-324.

116 Khoor A, Colby TV: Amyloidosis of the lung. Arch Pathol Lab Med 2017;141:247254.

117 Gillmore JD, Hawkins PN: Amyloidosis and the respiratory tract. Thorax 1999;54:444451.

118 Gertz MA, Comenzo R, Falk RH, Fermand JP, Hazenberg BP, Hawkins PN, et al: Definition of organ involvement and treatment response in immunoglobulin light chain amyloidosis (AL): a consensus opinion from the 10th International Symposium on Amyloid and Amyloidosis, Tours, France, 18-22 April 2004. Am J Hematol 2005;79: 319-328.

119 Picken MM, Herrera GA: The burden of "sticky" amyloid: typing challenges. Arch Pathol Lab Med 2007;131:850-851.

120 Vrana JA, Gamez JD, Madden BJ, Theis JD, Bergen HR, Dogan A: Classification of amyloidosis by laser microdissection and mass spectrometry-based proteomic analysis in clinical biopsy specimens. Blood 2009;114: 4957-4959.
21 O’Regan A, Fenlon HM, Beamis JF, Steele MP, Skinner M, Berk JL: Tracheobronchial amyloidosis. The Boston University experience from 1984 to 1999. Medicine (Baltimore) 2000;79:69-79.

-122 Hui AN, Koss MN, Hochholzer L, Wehunt WD: Amyloidosis presenting in the lower respiratory tract. Clinicopathologic, radiologic, immunohistochemical, and histochemical studies on 48 cases. Arch Pathol Lab Med 1986;110:212-218.

123 Cordier JF, Loire R, Brune J: Amyloidosis of the lower respiratory tract. Clinical and pathologic features in a series of 21 patients. Chest 1986;90:827-831.

124 Celli BR, Rubinow A, Cohen AS, Brody JS: Patterns of pulmonary involvement in systemic amyloidosis. Chest 1978;74:543-547.

125 Rubinow A, Celli BR, Cohen AS, Rigden BG, Brody JS: Localized amyloidosis of the lower respiratory tract. Am Rev Respir Dis 1978;118:603-611.

126 Utz JP, Swensen SJ, Gertz MA: Pulmonary amyloidosis. The Mayo Clinic experience from 1980 to 1993. Ann Intern Med 1996; 124:407-413.

127 Mahmood S, Bridoux F, Venner CP, Sachchithanantham S, Gilbertson JA, Rowczenio $D$, et al: Natural history and outcomes in localised immunoglobulin light-chain amyloidosis: a long-term observational study. Lancet Haematol 2015;2:e241-e250.

128 Thompson PJ, Citron KM: Amyloid and the lower respiratory tract. Thorax 1983;38:8487.

129 Crestani B, Monnier A, Kambouchner M, Battesti JP, Reynaud P, Valeyre D: Tracheobronchial amyloidosis with hilar lymphadenopathy associated with a serum monoclonal immunoglobulin. Eur Respir J 1993;6: 1569-1571.

130 Haddad F, Jammal M, Azar H, Mallat S, Nasr F, Dabar G, et al: A systemic amyloidosis presenting as a tracheobronchial amyloidosis (in French). Rev Med Interne 2010; 31:e4-e6.

131 Biewend ML, Menke DM, Calamia KT: The spectrum of localized amyloidosis: a case series of 20 patients and review of the literature. Amyloid Int J Exp Clin Investig 2006; 13:135-142.

132 Paccalin M, Hachulla E, Cazalet C, Tricot L, Carreiro M, Rubi M, et al: Localized amyloidosis: a survey of 35 French cases. Amyloid Int J Exp Clin Investig 2005;12:239245.

133 Setoguchi M, Hoshii Y, Kawano H, Ishihara $\mathrm{T}$ : Analysis of plasma cell clonality in localized AL amyloidosis. Amyloid Int J Exp Clin Investig 2000;7:41-45.

134 Borie R, Danel C, Molinier-Frenkel V, Prevot G, Deslee G, Debray MP, et al: Tracheobronchial amyloidosis: evidence for local Bcell clonal expansion. Eur Respir J 2012;39: 1042-1045. 
135 Toyoda M, Ebihara Y, Kato H, Kita S: Tracheobronchial AL amyloidosis: histologic, immunohistochemical, ultrastructural, and immunoelectron microscopic observations. Hum Pathol 1993;24:970-976.

136 Capizzi SA, Betancourt E, Prakash UB: Tracheobronchial amyloidosis. Mayo Clin Proc 2000;75:1148-1152.

137 Cordier J-F: Pulmonary amyloidosis in hematological disorders. Semin Respir Crit Care Med 2005;26:502-513.

138 Gillmore JD, Booth DR, Madhoo S, Pepys MB, Hawkins PN: Hereditary renal amyloidosis associated with variant lysozyme in a large English family. Nephrol Dial Transplant 1999;14:2639-2644.

-139 Piazza C, Cavaliere S, Foccoli P, Toninelli C, Bolzoni A, Peretti G: Endoscopic management of laryngo-tracheobronchial amyloidosis: a series of 32 patients. Eur Arch Otorhinolaryngol 2003;260:349-354.

140 Hamed G, Heffess CS, Shmookler BM, Wenig BM: Amyloid goiter. A clinicopathologic study of 14 cases and review of the literature. Am J Clin Pathol 1995; 104:306312 .

-141 Georgiades CS, Neyman EG, Barish MA, Fishman EK: Amyloidosis: review and CT manifestations. Radiographics 2004;24: 405-416.

142 Ding L, Li W, Wang K, Chen Y, Xu H, Wang $\mathrm{H}$, et al: Primary tracheobronchial amyloidosis in China: analysis of 64 cases and a review of literature. J Huazhong Univ Sci Technol Med Sci 2010;30:599-603.

-143 Boccuzzi F, Busso M, Cardinale L, Fava C: Primary tracheo-bronchial amyloidosis studied with 64-slice MDCT (2D and 3D reconstructions). Thorax 2011;66:929-930.

144 Serrano-Fernández ML, Alvarez-Maldonado P, Aristi-Urista G, Valero-Gómez A, Cicero-Sabido R, Redondo CN-P: Narrowband imaging bronchoscopy in tracheobronchial amyloidosis. J Bronchol Interv Pulmonol 2014;21:267-270.

145 Lu X, He B, Wang G, He B, Wang L, Chen Q: Bronchoscopic diagnosis and treatment of primary tracheobronchial amyloidosis: a retrospective analysis from China. BioMed Res Int 2017;2017:3425812.

-146 Alloubi I, Thumerel M, Bégueret H, Baste J-M, Velly J-F, Jougon J: Outcomes after bronchoscopic procedures for primary tracheobronchial amyloidosis: retrospective study of 6 cases. Pulm Med 2012;2012: 352719.

-147 Kalra S, Utz JP, Edell ES, Foote RL: Externalbeam radiation therapy in the treatment of diffuse tracheobronchial amyloidosis. Mayo Clin Proc 2001;76:853-856.

148 Neben-Wittich MA, Foote RL, Kalra S: External beam radiation therapy for tracheobronchial amyloidosis. Chest 2007;132: 262-267.
49 Truong MT, Kachnic LA, Grillone GA, Bohrs HK, Lee R, Sakai O, et al: Long-term results of conformal radiotherapy for progressive airway amyloidosis. Int J Radiat Oncol Biol Phys 2012;83:734-739.

150 Sommer P, Kumar G, Lipchik RJ, Patel JJ: Tracheobronchial amyloidosis managed with multimodality therapies. Ther Adv Respir Dis 2014;8:48-52.

151 Morales A, Pari M, López-Lisbona R, Cubero N, Dorca J, Rosell A: Colchicine treatment for tracheobronchial amyloidosis. Respir Int Rev Thorac Dis 2016;91:251-255.

152 Smith RR, Hutchins GM, Moore GW, Humphrey RL: Type and distribution of pulmonary parenchymal and vascular amyloid. Correlation with cardiac amyloid. Am J Med 1979;66:96-104.

153 Pitz MW, Gibson IW, Johnston JB: Isolated pulmonary amyloidosis: case report and review of the literature. Am J Hematol 2006; 81:212-213.

154 Howard ME, Ireton J, Daniels F, Langton D, Manolitsas ND, Fogarty P, et al: Pulmonary presentations of amyloidosis. Respirology 2001;6:61-64.

155 Zamora AC, White DB, Sykes A-MG, Hoskote SS, Moua T, Yi ES, et al: Amyloid-associated cystic lung disease. Chest 2016;149: 1223-1233.

156 Khoor A, Myers JL, Tazelaar HD, Kurtin PJ: Amyloid-like pulmonary nodules, including localized light-chain deposition: clinicopathologic analysis of three cases. Am J Clin Pathol 2004;121:200-204.

157 Kyle RA, Greipp PR: Amyloidosis (AL). Clinical and laboratory features in 229 cases. Mayo Clin Proc 1983;58:665-683.

158 Lantuejoul S, Moulai N, Quetant S, Brichon PY, Brambilla C, Brambilla E, et al: Unusual cystic presentation of pulmonary nodular amyloidosis associated with MALT-type lymphoma. Eur Respir J 2007;30:589-592.

159 Mekinian A, Jaccard A, Soussan M, Launay D, Berthier S, Federici L, et al: 18F-FDG $\mathrm{PET} / \mathrm{CT}$ in patients with amyloid lightchain amyloidosis: case-series and literature review. Amyloid Int J Exp Clin Investig 2012;19:94-98.

-160 Cappiello M, Pagano E, Vandemoortele T, Laroumagne S, Giusiano S, Dutau H, et al: Pseudotumoral pulmonary AL amyloidosis (in French). Rev Mal Respir 2014;31:61-65.

161 Cresner R, Mahmood S, Chen J, Rowan C, Wechalekar AD: Thoracic amyloidomas: two case reports of an evasive diagnosis. JRSM Open 2014;5:2054270414527280.

162 Quan X-Q, Yin T-J, Zhang C-T, Liu J, Qiao L-F, Ke C-S: (18)F-FDG PET/CT in patients with nodular pulmonary amyloidosis: case report and literature review. Case Rep Oncol 2014;7:789-798.

163 Glaudemans AWJM, Slart RHJA, Noordzij W, Dierckx RAJO, Hazenberg BPC: Utility of 18F-FDG PET(/CT) in patients with systemic and localized amyloidosis. Eur J Nucl Med Mol Imaging 2013;40:1095-1101.
64 Dong M-J, Zhao K, Liu Z-F, Wang G-L, Yang J: Primary pulmonary amyloidosis misdiagnosed as malignancy on dual-timepoint fluoro-deoxyglucose positron emission tomography/computed tomography: a case report and review of the literature. Oncol Lett 2015;9:591-594.

165 Hazenberg BPC, van Rijswijk MH, Lub-de Hooge MN, Vellenga E, Haagsma EB, Posthumus MD, et al: Diagnostic performance and prognostic value of extravascular retention of 123I-labeled serum amyloid P component in systemic amyloidosis. J Nucl Med Off Publ Soc Nucl Med 2007;48:865-872.

166 Grogg KL, Aubry M-C, Vrana JA, Theis JD, Dogan A: Nodular pulmonary amyloidosis is characterized by localized immunoglobulin deposition and is frequently associated with an indolent B-cell lymphoproliferative disorder. Am J Surg Pathol 2013;37:406412.

167 Lim JK, Lacy MQ, Kurtin PJ, Kyle RA, Gertz MA: Pulmonary marginal zone lymphoma of MALT type as a cause of localised pulmonary amyloidosis. J Clin Pathol 2001;54: 642-646.

168 Kambouchner M, Godmer P, Guillevin L, Raphaël M, Droz D, Martin A: Low grade marginal zone $B$ cell lymphoma of the breast associated with localised amyloidosis and corpora amylacea in a woman with long standing primary Sjögren's syndrome. J Clin Pathol 2003;56:74-77.

169 Telio D, Bailey D, Chen C, Crump M, Reece D, Kukreti V: Two distinct syndromes of lymphoma-associated AL amyloidosis: a case series and review of the literature. Am J Hematol 2010;85:805-808.

170 Sachchithanantham S, Roussel M, Palladini G, Klersy C, Mahmood S, Venner CP, et al: European collaborative study defining clinical profile outcomes and novel prognostic criteria in monoclonal immunoglobulin $\mathrm{M}$ related light chain amyloidosis. J Clin Oncol 2016;34:2037-2045.

171 Terrier B, Jaccard A, Harousseau J-L, Delarue R, Tournilhac O, Hunault-Berger M, et al: The clinical spectrum of IgM-related amyloidosis: a French nationwide retrospective study of 72 patients. Medicine (Baltimore) 2008;87:99-109.

172 Wechalekar AD, Lachmann HJ, Goodman HJB, Bradwell A, Hawkins PN, Gillmore JD: AL amyloidosis associated with IgM paraproteinemia: clinical profile and treatment outcome. Blood 2008;112:4009-4016.

173 Suzuki H, Matsui K, Hirashima T, Kobayashi M, Sasada S, Okamato N, et al: Three cases of the nodular pulmonary amyloidosis with a longterm observation. Intern Med Tokyo Jpn 2006;45:283-286.

174 Morgenthal S, Bayer R, Schneider E, Zachäus M, Röcken C, Dreßler J, et al: Nodular pulmonary amyloidosis with spontaneous fatal blood aspiration. Forensic Sci Int 2016; 262:e1-e4.
The Lung in Dysregulated States of Humoral Immunity
Respiration 2017;94:389-404 DOI: $10.1159 / 000480297$ 
175 Gobert D, Paule R, Ponard D, Levy P, Frémeaux-Bacchi V, Bouillet L, et al: A nationwide study of acquired C1-inhibitor deficiency in France: characteristics and treatment responses in 92 patients. Medicine (Baltimore) 2016;95:e4363.

-176 Ussavarungsi K, Yi ES, Maleszewski JJ, Kurtin PJ, Dasari S, Theis JD, et al: Clinical relevance of pulmonary amyloidosis: an analysis of 76 autopsy-derived cases. Eur Respir J 2017;49:1602313.

-177 Abraham RS, Geyer SM, Price-Troska TL, Allmer C, Kyle RA, Gertz MA, et al: Immunoglobulin light chain variable $(\mathrm{V})$ region genes influence clinical presentation and outcome in light chain-associated amyloidosis (AL). Blood 2003;101:3801-3808.

178 Gertz MA, Lacy MQ, Dispenzieri A: Amyloidosis: recognition, confirmation, prognosis, and therapy. Mayo Clin Proc 1999;74: 490-494.

179 Gertz MA, Kyle RA, Noel P: Primary systemic amyloidosis: a rare complication of immunoglobulin $\mathrm{M}$ monoclonal gammopathies and Waldenström's macroglobulinemia. J Clin Oncol 1993;11:914-920.

180 Jaccard A, Moreau P, Leblond V, Leleu X, Benboubker L, Hermine O, et al: High-dose melphalan versus melphalan plus dexamethasone for AL amyloidosis. N Engl J Med 2007;357:1083-1093.

181 Cordier J-F: Pulmonary amyloidosis and non-amyloid immunoglobulin deposits (in French). Rev Mal Respir 2008;25:743-765.

-182 Ohdama S, Akagawa S, Matsubara O, Yoshizawa Y: Primary diffuse alveolar septal amyloidosis with multiple cysts and calcification. Eur Respir J 1996;9:1569-1571.

183 Pickford HA, Swensen SJ, Utz JP: Thoracic cross-sectional imaging of amyloidosis. AJR Am J Roentgenol 1997;168:351-355.

184 Czeyda-Pommersheim F, Hwang M, Chen SS, Strollo D, Fuhrman C, Bhalla S: Amyloidosis: modern cross-sectional imaging. Radiographics 2015;35:1381-1392.

185 Sterlacci W, Veits L, Moser P, Steiner H-J, Rüscher S, Jamnig H, et al: Idiopathic systemic amyloidosis primarily affecting the lungs with fatal pulmonary haemorrhage due to vascular involvement. Pathol Oncol Res 2009;15:133-136.

186 Dingli D, Utz JP, Gertz MA: Pulmonary hypertension in patients with amyloidosis. Chest 2001;120:1735-1738.

187 Eder L, Bitterman H: Image in clinical medicine. Amyloid purpura. N Engl J Med 2007; 356:2406.

188 Lehtonen J, Kettunen P: Pulmonary hypertension as a dominant clinical picture in a case of amyloidosis and smoldering multiple myeloma. Int J Cardiol 2007;115:e29 e30.

189 Lutz AE, Schneider U, Ehlerding G, Frenzel $\mathrm{H}$, Koch KM, Kühn K: Right ventricular cardiac failure and pulmonary hypertension in a long-term dialysis patient - unusual presentation of visceral beta 2-microglobulin amyloidosis. Nephrol Dial Transplant 1995; 10:555-558.

190 Shiue ST, McNally DP: Pulmonary hypertension from prominent vascular involvement in diffuse amyloidosis. Arch Intern Med 1988;148:687-689.

191 Berk JL, Keane J, Seldin DC, Sanchorawala V, Koyama J, Dember LM, et al: Persistent pleural effusions in primary systemic amyloidosis: etiology and prognosis. Chest 2003; 124:969-977.

192 Urban BA, Fishman EK, Goldman SM, Scott WW, Jones B, Humphrey RL, et al: CT evaluation of amyloidosis: spectrum of disease. Radiographics 1993;13:1295-1308.

193 Jenkins MC, Potter M: Calcified pseudotumoural mediastinal amyloidosis. Thorax 1991;46:686-687.

194 Naschitz JE, Yeshurun D, Pick AI: Intrathoracic amyloid lymphadenopathy. Respir Int Rev Thorac Dis 1986;49:73-76.

195 Fujita T, Ichikawa S, Okitsu Y, Fukuhara N, Yoshinaga T, Yazaki M, et al: Primary AL amyloidosis presenting with systemic lymphadenopathy with calcification. Int $\mathrm{J}$ Hematol 2016;104:641-643.

196 Natu S, Hoffman J, Siddiqui M, Hobday C, Shrimankar J, Harrison R: The role of endobronchial ultrasound guided transbronchial needle aspiration cytology in the investigation of mediastinal lymphadenopathy and masses, the North Tees experience. J Clin Pathol 2010;63:445-451.

197 Ishiguro T, Takayanagi N, Katoh N, Shimizu Y, Hoshi T, Yanagisawa $\mathrm{T}$, et al: Waldenström's macroglobulinemia accompanying systemic amyloidosis: the usefulness of endobronchial ultrasound-guided transbronchial needle aspiration for detecting amyloid deposits. Intern Med 2014;53: 2789-2793.

198 VanderLaan PA, Wang HH, Majid A, Folch E: Endobronchial ultrasound-guided transbronchial needle aspiration (EBUS-TBNA) an overview and update for the cytopathologist. Cancer Cytopathol 2014;122:561-576.

199 Randall RE, Williamson WC, Mullinax F, Tung MY, Still WJ: Manifestations of systemic light chain deposition. Am J Med 1976;60:293-299.

200 Buxbaum JN, Chuba JV, Hellman GC, Solomon A, Gallo GR: Monoclonal immunoglobulin deposition disease: light chain and light and heavy chain deposition diseases and their relation to light chain amyloidosis. Clinical features, immunopathology, and molecular analysis. Ann Intern Med 1990; 112:455-464.

201 Colombat M, Stern M, Groussard O, Droz D, Brauner M, Valeyre D, et al: Pulmonary cystic disorder related to light chain deposition disease. Am J Respir Crit Care Med 2006;173:777-780.
02 Bhargava P, Rushin JM, Rusnock EJ, Hefter LG, Franks TJ, Sabnis SG, et al: Pulmonary light chain deposition disease: report of five cases and review of the literature. Am J Surg Pathol 2007;31:267-276.

203 Sheard S, Nicholson AG, Edmunds L, Wotherspoon AC, Hansell DM: Pulmonary light-chain deposition disease: CT and pathology findings in nine patients. Clin Radiol 2015;70:515-522.

204 Raoof S, Bondalapati P, Vydyula R, Ryu JH, Gupta N, Raoof S, et al: Cystic lung diseases: algorithmic approach. Chest 2016;150:945965.

205 Piard F, Yaziji N, Jarry O, Assem M, Martin L, Bernard A, et al: Solitary plasmacytoma of the lung with light chain extracellular deposits: a case report and review of the literature. Histopathology 1998;32:356-361.

206 Colombat M, Mal H, Copie-Bergman C, Diebold J, Damotte D, Callard P, et al: Primary cystic lung light chain deposition disease: a clinicopathologic entity derived from unmutated B cells with a stereotyped IGHV4-34/IGKV1 receptor. Blood 2008; 112:2004-2012.

207 Borgne AL, Prévot G, Rouquette I, Huynh A, Têtu L, Projetti F, et al: Blood stem cell transplantation to treat cystic lung light chain deposition disease. Eur Respir J 2015; 46:1199-1202.

208 Bieliauskas S, Tubbs RR, Bacon CM, Eshoa C, Foucar K, Gibson SE, et al: Gamma heavy-chain disease: defining the spectrum of associated lymphoproliferative disorders through analysis of 13 cases. Am J Surg Pathol 2012;36:534-543.

209 Ionescu DN, Pierson DM, Qing G, Li M, Colby TV, Leslie KO: Pulmonary crystalstoring histiocytoma. Arch Pathol Lab Med 2005; 129:1159-1163.

210 Jones D, Renshaw AA: Recurrent crystalstoring histiocytosis of the lung in a patient without a clonal lymphoproliferative disorder. Arch Pathol Lab Med 1996;120:978-980.

211 Rossi G, Morandi U, Nannini N, Fontana G, Pifferi M, Casali C: Crystal-storing histiocytosis presenting with pleural disease. Histopathology 2010;56:403-405.

212 Todd WU, Drabick JJ, Benninghoff MG, Frauenhoffer EE, Zander DS: Pulmonary crystal-storing histiocytosis diagnosed by computed tomography-guided fine-needle aspiration. Diagn Cytopathol 2010;38:274278.

213 Blain H, Cacoub P, Musset L, CostedoatChalumeau N, Silberstein C, Chosidow O, et al: Cryofibrinogenaemia: a study of 49 patients. Clin Exp Immunol 2000;120:253-260.

214 Nash JW, Ross P, Neil Crowson A, Taylor J, Morales JE, Yunger TM, et al: The histopathologic spectrum of cryofibrinogenemia in four anatomic sites. Skin, lung, muscle, and kidney. Am J Clin Pathol 2003;119:114122. 